\title{
Genetic and Morphological Evidence that Phoma sclerotioides, Causal Agent of Brown Root Rot of Alfalfa, Is Composed of a Species Complex
}

\author{
Michael J. Wunsch and Gary C. Bergstrom
}

Department of Plant Pathology and Plant-Microbe Biology, 334 Plant Science, Cornell University, Ithaca, NY 14853.

Current address of M. J. Wunsch: Carrington Research Extension Center, North Dakota State University, Carrington 58421-0219. Accepted for publication 11 October 2010.

\section{ABSTRACT}

Wunsch, M. J., and Bergstrom, G. C. 2011. Genetic and morphological evidence that Phoma sclerotioides, causal agent of brown root rot of alfalfa, is composed of a species complex. Phytopathology 101:594-610.

Phoma sclerotioides, causal agent of brown root rot of alfalfa, causes severe root and crown lesions on alfalfa and other perennial forage legumes in regions with harsh winters. Isolates of $P$. sclerotioides exhibit diverse cultural morphologies on potato dextrose agar (PDA), suggesting that they may exhibit a high degree of genetic diversity. To investigate the genetic relatedness of $P$. sclerotioides isolates, 154 isolates from North America were sequenced at 10 loci. Maximum parsimony and maximum likelihood analyses of the complete 10-locus data set placed isolates into

Diseases associated with plant-pathogenic fungi within the genus Phoma are frequently caused by species complexes, the components of which may have subtle or pronounced differences in morphology. Phoma medicaginis var. medicaginis and $P$. medicaginis var. macrospora, which differ in conidial size and septation, both contribute to spring black stem and leaf spot of alfalfa (Medicago sativa L.) (9). At least eight subtypes of $P$. lingam cause black leg of oilseed rape (Brassica napus L.), with two subtypes corresponding to the teleomorphic state Leptosphaeria maculans and six corresponding to L. biglobosa $(24,35)$. $P$. destructiva var. destructiva and $P$. destructiva var. diversispora, differing in conidial size and septation, both contribute to a leaf and stem rot of tomato (Solanum lycopersicum L.) (13). Similar species complexes associated with specific diseases have been recognized within $P$. enteroleuca, an opportunistic pathogen of trees and shrubs; within $P$. exigua causing foliar blight of Vinca sp. and foliar and bark lesions on Forsythia hybrids; within $P$. macrostoma, an opportunistic parasite of woody plants; and within $P$. pomorum, a plurivorous pathogen commonly associated with leaf spots on members of the family Rosaceae (8). For those Phoma species complexes in which genetic differentiation has been evaluated, morphological differences correspond closely to genetic differences $(1,24,35)$.

From a phytopathology perspective, Phoma species complexes are significant because individual components of a complex can differ in aggressiveness, timing of infection, and temperature adaptation. On alfalfa, $P$. medicaginis var. macrospora is associ-

Corresponding author: Gary C. Bergstrom; E-mail address: gcb3@ cornell.edu

* The $e$-Xtra logo stands for "electronic extra" and indicates that the online version contains two supplemental tables. Figure 4 appears in color online.

doi:10.1094/PHYTO-04-10-0107

(C) 2011 The American Phytopathological Society multiple strongly supported clades, and analyses of gene-jackknife and single-gene partitions of the data set indicated robust support for six major clades and three subclades. Genetic differences corresponded closely to differences in conidial size and septation, pycnidial neck length, mycelial pigmentation, and growth rate in axenic culture at 18 and $25^{\circ} \mathrm{C}$. Isolates exhibited morphologies broadly consistent with the species description of $P$. sclerotioides, and new species were not designated. On the basis of genetic and morphological differences, we propose establishing seven infraspecific varieties within $P$. sclerotioides: $P$. sclerotioides var. sclerotioides, champlainii, viridis, obscurus, steubenii, macrospora, and saskatchewanii. All varieties of $P$. sclerotioides caused brown root rot of alfalfa and grew well at low temperatures. ated with more severe spring black stem and leaf spot symptoms than $P$. medicaginis var. medicaginis (9). On oilseed rape, $L$. maculans produces damaging cortical lesions and cankers on stems while L. biglobosa produces mild cortical lesions and blackening of pith tissues but no cankers, and infection by $L$. maculans starts later but progresses more rapidly than infection by L. biglobosa (20). Of three genetically distinct subtypes of $P$. cucurbitacearum causing gummy stem blight of cucurbits, one causes severe disease symptoms while the others produce only mild symptoms (30). On members of the family Rosaceae, $P$. pomorum var. pomorum and $P$. pomorum var. calorpreferens are both associated with leaf spots but $P$. pomorum var. calorpreferens is more heat tolerant (8).

Brown root rot (BRR) of alfalfa and other perennial legumes, caused by $P$. sclerotioides G. Preuss ex Sacc. (synonym Plenodomus meliloti Dearn. \& Sanford), is associated with light to dark brown root and crown lesions, often with a darker border, that develop as plants emerge from winter dormancy. Lesions that girdle the taproot at or near the crown lead to plant mortality. In North America, BRR is most severe in central and northern Canada, where it is one of the most important diseases of sweet clover and causes considerable alfalfa mortality (11). In central Saskatchewan, alfalfa mortality associated with BRR can exceed $60 \%$ on susceptible alfalfa cultivars 2 years after seeding and can reach $40 \% 1$ year after seeding (6). In the contiguous United States, BRR has been reported in the Rocky Mountain states south to New Mexico $(17,38)$, in the upper Midwest $(21,22)$, and in the northeast south to Pennsylvania $(39,40)$.

Phoma sclerotioides displays pronounced variability in the pigmentation and abundance of aerial mycelium produced on potato dextrose agar (PDA). Single-conidium isolates identified as $P$. sclerotioides by pycnidial and conidial morphology on sterilized alfalfa root sections and autoclaved barley (40) produce white, tan, brown, green, or dark-gray mycelium on PDA, with 
production of aerial mycelium either abundant or sparse. The morphologies represent diversity among isolates and not morphological plasticity; when started from frozen stocks stored at $-80^{\circ} \mathrm{C}$, individual isolates repeatedly produce the same cultural characteristics on PDA (M. J. Wunsch, personal observation). Variability in cultural morphology of $P$. sclerotioides on PDA has also been reported by Gray et al. (12).

The pronounced morphological variability of $P$. sclerotioides isolates suggests that BRR may be caused by a species complex. The current study attempts to address this question by (i) rigorously evaluating whether isolates representing diverse cultural morphologies correspond to the species description of $P$. sclerotioides, (ii) confirming that isolates representing diverse cultural morphologies cause BRR and are adapted to low temperatures, and (iii) assessing morphological and genetic differentiation among isolates. Because components of species complexes can differ in properties such as aggressiveness and host range, investigating whether BRR is composed of a species complex is critical for developing effective management strategies for BRR. The species description of P. sclerotioides is based primarily on conidial and pycnidial characteristics in vivo (8). Pathogenicity testing was conducted under controlled conditions using single-conidium isolates, and diseased plants from pathogenicity testing were used for in vivo characterization of isolates. Morphological characteristics in vivo and in vitro were compared across isolates, and in vitro growth at $3,10,18$, and $25^{\circ} \mathrm{C}$ was assessed. A broad collection of isolates was sequenced at multiple loci, and phylogenetic analyses of the sequence data were conducted by maximum parsimony and maximum likelihood.

\section{MATERIALS AND METHODS}

Fungal strains and culture maintenance. Isolates WI LMHB, WI LMH-C, MN JNL-1a, and WI LMN-D from Minnesota and Wisconsin were isolated from symptomatic roots sent by D. A. Samac (United States Department of Agriculture-Agricultural Research Service, St. Paul, MN), and isolate WyoBerg from Wyoming was provided by F. A. Gray (University of Wyoming, Laramie). All other isolates were obtained from previously described surveys of alfalfa production fields (38-40) and additional surveys conducted in Montana and Wisconsin in 2006, New York in 2007, and Saskatchewan in 2007. Isolates were obtained from alfalfa root, crown, leaf, and overwintered (dead) stem tissues, and one isolate was obtained from reed canarygrass (Phalaris arundinacea L.) roots. Symptomatic tissue segments were excised, surface sterilized in $0.6 \%$ sodium hypochlorite and $70 \%$ ethanol, rinsed in sterile distilled water, plated onto $1.5 \%$ water agar, and incubated for 3 to 6 months at $10^{\circ} \mathrm{C}$ under continuous white fluorescent light with average luminescence of 2,000 lx. Pycnidia characteristic of Phoma sclerotioides were harvested and single-conidium isolates were established on PDA (Difco Laboratories, Becton, Dickson and Co., Sparks, MD). Singleconidium isolates were grown for 2 to 4 months at $10^{\circ} \mathrm{C}$ under continuous white fluorescent light, and cultures were harvested and stored in $15 \%$ glycerol at $-80^{\circ} \mathrm{C}$. For a subset of the isolates from Montana, New York, Vermont, and New Hampshire, pathogen identity was confirmed by assessing pycnidial morphology on autoclaved barley and on surface-disinfested healthy root segments obtained from greenhouse-grown alfalfa (40). Diagnostic polymerase chain reaction (PCR) was conducted on all isolates using pathogen-specific primers (23).

DNA extraction, amplification, purification, and sequencing. Cultures of 155 P. sclerotioides isolates and $1 P$. medicaginis isolate were established on PDA from frozen stocks, transferred to potato dextrose broth (PDB) (Difco Laboratories, Becton, Dickson and Co.), and grown for 4 to 8 weeks at $10^{\circ} \mathrm{C}$. Mycelium was harvested by decanting the broth, rinsing once in sterile distilled water, and centrifuging. Rinsed mycelium was lyo- philized and DNA was extracted using a DNeasy Plant Mini Kit (Qiagen Inc., Valencia, CA) according to the manufacturer's instructions.

Ten loci were amplified and sequenced: the internal transcribed spacer (ITS) 1, 5.8S, and ITS2 of the rDNA; intron-spanning regions of actin (ACT), $\alpha$-tubulin (AT), $\beta$-tubulin (BT), elongation factor 1- $\alpha(\mathrm{EF} 1 \alpha)$, glyceraldehyde 3-phosphate dehydrogenase (G3P), and histone (HIS) genes; a portion of a mitochondrial NADH dehydrogenase (NAD) gene; and regions of the rDNA intergenic spacer flanking the 28S ribosomal subunit (IGSNL) and flanking the $18 \mathrm{~S}$ ribosomal subunit (IGS-NS). Sequences were generated as a part of a broader effort to investigate the population genetics of $P$. sclerotioides and to generate diagnostic primers for subtypes of $P$. sclerotioides, projects that required sequence data from a relatively large number of loci. Amplifications were conducted in $25-\mu \mathrm{l}$ reactions containing $1.5 \mu \mathrm{l}$ of template DNA, 1× Takara Ex Taq buffer (Clontech Laboratories, Mountain View, CA), $0.8 \mathrm{mM}$ dNTPs, $1 \mu \mathrm{M}$ each of the forward and reverse primers, and 0.625 units of Ex Taq DNA polymerase, hot start version (Clontech Laboratories). Amplification and sequencing were conducted with a combination of previously designed primers $(5,27,37)$ and novel primers; all primers are presented in the supplemental materials. For P. sclerotioides, PCR was conducted in a PTC-100 Peltier Thermal Cycler (MJ Research, Waltham, MA) with the following melting, annealing, and extension temperatures: 94,54 , and $67^{\circ} \mathrm{C}$ for ACT; 94, 58, and $69^{\circ} \mathrm{C}$ for AT; 94,54 , and $67^{\circ} \mathrm{C}$ for BT; 94,58 , and $68^{\circ} \mathrm{C}$ for $\mathrm{EF} 1 \alpha$; 94, 63, and $71^{\circ} \mathrm{C}$ for G3P; 94,59 , and $71^{\circ} \mathrm{C}$ for HIS; 94, 50 , and $60^{\circ} \mathrm{C}$ for NAD; 94,61 , and $70^{\circ} \mathrm{C}$ for ITS; $94,59.5$, and $68^{\circ} \mathrm{C}$ for IGS with primers CNS1 and NL11; and 94, 62, and $70^{\circ} \mathrm{C}$ for IGS with primers CNS1 and R10. For P. medicaginis, the extension temperature was lowered to $68^{\circ} \mathrm{C}$ for $\mathrm{AT}$ and to $67^{\circ} \mathrm{C}$ for EF1 $\alpha$ but otherwise thermocycler conditions were the same. For all loci except NAD and IGS, an initial $60 \mathrm{~s}$ at the melting temperature was followed by 40 cycles of $45 \mathrm{~s}$ at the melting temperature, $45 \mathrm{~s}$ at the annealing temperature, and $60 \mathrm{~s}$ at the extension temperature; PCR was concluded with 5 min at the extension temperature and a $4{ }^{\circ} \mathrm{C}$ bath. For NAD, the extension temperature was held for $80 \mathrm{~s}$ during the 40 cycles and, for IGS, the melting, annealing, and extension temperatures were held for $30 \mathrm{~s}, 30 \mathrm{~s}$, and $3 \mathrm{~min} 40 \mathrm{~s}$, respectively, during the 40 cycles, and the final extension temperature was held for $6 \mathrm{~min}$. Otherwise, thermocycler conditions were the same as for other loci. Primers ITS1 and ITS4 (37) were used to amplify and sequence the ITS region; a combination of published and novel primers were used for other loci. Novel primers were designed by manual comparison of conserved regions among sequences from Asocomycete genera. Isolate Fr 1-3-1RC was sequenced at 6 loci; all other isolates and a $P$. medicaginis isolate were sequenced at all 10 loci. Sequencing was conducted at the Cornell University Life Sciences Core Laboratories Center (Ithaca, NY). Trace files were visualized with Finch TV (Geospiza, Seattle, WA) and SeqMan (Lasergene 7.2.1; DNASTAR, Madison, WI), and sequences were edited in SeqMan. The edited sequences were deposited in GenBank under accession numbers HM157290 to HM158849.

Phylogenetic analyses. Sequences were aligned with Clustal $\mathrm{W}$ in MegAlign (Lasergene 7.2.1; DNASTAR) using default gap and gap-length parameters of 15.00 and 6.66, respectively. Alignments were manually edited to resolve inconsistencies in the alignment of individual regions of sequence. The edited sequence alignment has been deposited in TreeBASE (submission ID 10892).

To evaluate genetic differentiation within $P$. sclerotioides, maximum parsimony (MP) and maximum likelihood (ML) phylogenetic analyses were conducted on a 10-locus data set of $154 P$. sclerotioides isolates (all except Fr 1-3-1RC) and $1 P$. medicaginis isolate. MP and ML analyses were conducted on the 10-locus 
concatenated data set, with each single locus, and with every combination of nine concatenated loci as well as the eight loci excluding the IGS region (gene-jackknife analyses) (14). Genejackknife analyses permit assessment of whether support for individual clades in the full (10-locus) analysis is driven by a single locus or by a signal derived from multiple loci (14). P. medicaginis was utilized as an outgroup in all analyses; $P$. medicaginis is a member of the Didymellaceae, a subclade within the genus Phoma that is sister to the Leptosphaeriaceae, the subclade to which $P$. sclerotioides pertains (2).

To evaluate the relationship of $P$. sclerotioides to other Phoma spp., MP and ML phylogenetic analyses were conducted on a data set of ITS sequences. The data set included 25 P. sclerotioides isolates with unique ITS haplotypes, 83 isolates of other Phoma spp. and related genera, and an outgroup (Saccharomyces cerevisae strain CBS 1171). For all non-P. sclerotioides isolates except $P$. medicaginis, sequences were generated in previously published studies $(3,4,10,19,24,25,31)$ and obtained from GenBank.

Unweighted MP analyses were conducted with PAUP* version $4.0 \mathrm{~b} 10$ (32). Heuristic searches for the most parsimonious trees were conducted with 1,000 random addition replicates and tree bisection with reconnection branch swapping. To reduce computational time, rearrangements per replicate were limited to $10,000,000$. Gaps were treated as missing data, and trees were rooted with $P$. medicaginis. Clade stability was assessed with 1,000 bootstrap replicates. Bootstrap analysis was implemented with a heuristic search in PAUP* using 1,000 random addition sequences per replicate and tree bisection with reconnection branch swapping. To reduce computational time, random additions per replicate were limited to 10,000 during bootstrap analyses.

ML analyses were conducted with GARLI v. $0.96 \mathrm{~b} 8$ (42). A minimum of 20 runs was conducted until at least two searches from different starting points converged within one likelihood unit of the best tree. For each analysis, results from the best run were chosen. Nodal support was assessed by analyzing 1,000 bootstrap replicates, with a single run conducted per replicate. Nucleotide substitution models for ML analyses were selected with the Akaike Information Criterion implemented in ModelTest 3.7 (28). For the analysis of the ITS region of Phoma spp. and related genera, a TrN + I (estimation of invariant sites) + G (nucleotide substitution rates assumed to be gamma distributed) model of nucleotide substitution was used. For the analysis of genetic diversity within $P$. sclerotioides, a $\mathrm{TrN}+\mathrm{I}+\mathrm{G}$ model of nucleotide substitution was used for the full concatenated 10-locus data set. For gene-jackknife analyses, the following models were utilized: $\mathrm{HKY}+\mathrm{I}+\mathrm{G}$ when excluding ACT, K81 uf $+\mathrm{I}+\mathrm{G}$ when excluding AT, $\mathrm{K} 81+\mathrm{I}+\mathrm{G}$ when excluding $\mathrm{BT}$, TIM $+\mathrm{I}+\mathrm{G}$ when excluding $\mathrm{EF} 1 \alpha$, $\mathrm{HKY}+\mathrm{I}+\mathrm{G}$ when excluding $\mathrm{G} 3 \mathrm{P}, \mathrm{TrN}+\mathrm{I}+\mathrm{G}$ when excluding HIS, $\mathrm{K} 81 \mathrm{uf}+\mathrm{I}+\mathrm{G}$ when excluding both IGS regions, TIM+I+G when excluding IGS-NL, SYM $+\mathrm{I}+\mathrm{G}$ when excluding IGS-NS, $\mathrm{HKY}+\mathrm{I}+\mathrm{G}$ when excluding ITS, and $\mathrm{TrN}+\mathrm{I}+\mathrm{G}$ when excluding NAD. For single-gene analyses, the following models were utilized: $\operatorname{TrN}+\mathrm{I}$ for $\mathrm{ACT}, \mathrm{TIM}+\mathrm{I}+\mathrm{G}$ for $\mathrm{AT}, \mathrm{HKY}+\mathrm{G}$ for $\mathrm{BT}$, $\operatorname{TrN}+\mathrm{G}$ for $\mathrm{EF} 1 \alpha, \operatorname{TrN}+\mathrm{G}$ for $\mathrm{G} 3 \mathrm{P}, \mathrm{TrN}+\mathrm{I}+\mathrm{G}$ for $\mathrm{HIS}, \mathrm{TVM}+\mathrm{G}$ for IGS-NL, GTR+G for IGS-NS, TVM+G for ITS, and $\mathrm{GTR}+\mathrm{I}+\mathrm{G}$ for NAD.

Congruence of $50 \%$ bootstrap majority trees generated by MP and ML analyses were assessed with Kishino-Hasegawa $(\mathrm{KH})$ and Templeton Wilcoxon signed rank (WS-R) tests implemented in PAUP*. Congruence was evaluated for trees generated from the ITS data set of Phoma isolates and the concatenated 10-locus data set of $P$. sclerotioides isolates.

Pathogenicity testing and morphological characterization in vivo. Individual plants of 'Vernal' alfalfa were grown in the greenhouse in SC10 Cone-Tainers $(3.8 \mathrm{~cm}$ in diameter, $21 \mathrm{~cm}$ deep; Stuewe and Sons, Inc., Corvallis, OR) in a 1:2:1 mix (by volume) of peat moss, autoclaved loam soil, and autoclaved sand. Six months after seeding, soil was removed from the first $4 \mathrm{~cm}$ of the root, five to six barley grains either colonized by $P$. sclerotioides or soaked and autoclaved (control) were placed against the taproot, and soil was replaced. Barley grain inoculum was prepared by transferring single-conidium isolates (established on PDA from frozen stocks) to soaked, autoclaved barley grains and incubating for 3 months at $10^{\circ} \mathrm{C}$ under continuous white fluorescent light. Fourteen treatments were evaluated: isolates NY Chz17r, NY Chz2-14cr, NY Chz7-2r, NY Chz10-18r, NY Chz17-19cr, CO 7-2-10a, NY Fr1-3-1RC, ME 5-2-5r, ME 1-3-11lf, MT 2-1-3, MT 3-1-5, MT 3-3-2a, MT 4-4-12, and an autoclaved barley control. Isolates were selected that represented the breadth of genetic diversity within $P$. sclerotioides. From the seven major clades identified in phylogenetic analyses of $P$. sclerotioides, one isolate was selected from each of clades 2, 6, and 7 (P. sclerotioides var. champlainii, macrospora, and saskatchewanii); two isolates were selected from each of clades 3 and 4 (var. viridis and obscurus); and three isolates were selected from each of clades 1 and 5 (var. sclerotioides and steubenii). Two to three isolates were tested from each of clades $1,3,4$, and 5 because of their broader geographic distribution relative to clades 2,6 , and 7 . Twelve plants were subjected to each treatment in each replicate of the experiment, and the experiment was repeated three times. A randomized complete block design was used. After inoculation, plants were moved to a growth chamber and incubated at $4^{\circ} \mathrm{C}$ for 6 weeks, -1 to $+1^{\circ} \mathrm{C}$ for 5 weeks, -2 to $+1^{\circ} \mathrm{C}$ for 12 weeks, $3^{\circ} \mathrm{C}$ for 4 weeks, and $10^{\circ} \mathrm{C}$ for 4 weeks. At the coldest temperature treatment $\left(-2\right.$ to $\left.+1{ }^{\circ} \mathrm{C}\right)$, plants were incubated in complete darkness; at all other temperatures, plants were incubated under a cycle of $16 \mathrm{~h}$ of light and $8 \mathrm{~h}$ of darkness. At the conclusion of the experiment, plant mortality was recorded, plants were uprooted, taproots were washed, and root and crown rot severity was assessed. Disease severity was evaluated on a 0 to 10 scale, with $0=$ no disease, $1=0.1$ to $10 \%$ of taproot lesioned, $2=10.1$ to $20 \%$ of taproot lesioned, $\ldots$, and $10=90.1$ to $100 \%$ of taproot lesioned. Pycnosclerotia, immature pycnidia composed of outer cells with scleroplectenchymatous cell walls and inner cells with thin cell walls but no conidiogenous cells or conidia (8), were produced in or on lesions in all inoculated treatments but no mature pycnidia were found.

To generate mature pycnidia for in vivo morphological characterization, lesioned taproot segments bearing pycnosclerotia were transferred to moist chambers and incubated at $10^{\circ} \mathrm{C}$ under continuous light. Moist chambers were arranged in a complete randomized design in the incubator. After 1 month in moist chambers, pycnidial sections were prepared with a freezing microtome for all isolates, and conidial and pycnidial morphology of all isolates except NY Chz7-2r and NY Chz17-19cr were assessed. Pycnidia of isolates NY Chz7-2r and NY Chz17-19cr matured more slowly, and these isolates were assessed after 3 months in moist chambers. Digital photographs of mature pycnidia were taken under a dissecting microscope and digital photographs of conidia suspended in water were taken with a compound microscope. Conidial and pycnidial dimensions, conidial guttule numbers, and pycnidial neck numbers were assessed from the digital images. PDF Measure It v.1.06 (Traction Software, South Devon, UK), a plug-in to Adobe Acrobat 9 Pro (Adobe Systems, Inc., San Jose, CA), was used for measurements. Pycnidia and conidia used for morphological characterization were drawn from all three replicates of the inoculation experiment. Isolate NY Fr13-1RC was not evaluated morphologically because of insufficient production of pycnidia.

Morphological characterization in vitro. Thirty-three isolates representing all major clades identified in phylogenetic analyses were grown on PDA from frozen stocks. Isolates were selected to represent the breadth of genetic diversity within $P$. sclerotioides. Four isolates were included from each major clade identified in 
phylogenetic analyses except clades 1,2 , and 5 (P. sclerotioides var. sclerotioies, champlainii, and steubenii). Nine isolates were included from clade 1 (var. sclerotioides) because of the prevalence of the clade in western North America and the high genetic diversity within the clade, only three isolates were included from clade 2 (var. champlainii) because a fourth was not available, and five isolates were included from clade 5 (var. steubenii) because of the prevalence of the clade in eastern North America. After assessing cultures for contamination, each culture was transferred to PDA and grown at $10^{\circ} \mathrm{C}$ under continuous white fluorescent light with average luminescence of 2,000 lx for 1 month. Two cultures of each isolate were established, and a completely randomized design was used for incubation of the cultures. Two months after culture establishment, each isolate was photographed to document culture appearance. Three months after culture establishment, in vitro conidial and pycnidial morphology of each isolate was evaluated using a mixture of conidia and pycnidia from both cultures of each isolate. Pycnidia were excised and placed individually on slides, and pycnidial dimensions and neck numbers were assessed directly under a compound microscope or from digital photographs taken under a compound microscope. Conidia were suspended in water, and digital photographs taken under a compound microscope were used to measure conidial dimensions and record conidial guttule numbers.

In vitro growth rates. Cultures of 21 isolates representing all major clades identified in phylogenetic analyses were grown on PDA from frozen stocks. Isolates were selected that represented the breadth of genetic diversity within $P$. sclerotioides. From the major clades identified in phylogenetic analyses of $P$. sclerotioides, three isolates were selected from each of clades 3 and 5 (var. viridis and steubenii), seven isolates were selected from clade 1 (var. sclerotioides), and two isolates were evaluated from clades 2, 4, 6, and 7 (var. champlainii, obscurus, macrospora, and saskatchewanii). A higher number of isolates was evaluated from clades 1,3 , and 5 because of the prevalence of these clades within North America and because of the high genetic diversity found within clade 1 (var. sclerotioides). Three months after culture establishment, conidia were harvested from each isolate, suspended in water, plated onto PDA, and incubated for $24 \mathrm{~h}$ under continuous fluorescent light at $10^{\circ} \mathrm{C}$. Single germinating conidia were transferred to PDA. Single-conidium cultures were incubated at $3,10,18$, or $25^{\circ} \mathrm{C}$ in complete darkness for 24 days, and radial growth of the cultures was measured. The 10 and $18^{\circ} \mathrm{C}$ temperature treatments were evaluated because they approximate the temperatures previously reported as optimal for $P$. sclerotioides $(16,29)$, the $3^{\circ} \mathrm{C}$ treatment was included to assess growth at temperatures near freezing, and the $25^{\circ} \mathrm{C}$ temperature was included because it approximates the temperature previously reported as the upper threshold for P. sclerotioides growth (29). The incubation period of 24 days was selected to maximize the ability to differentiate treatments; after 24 days, cultures of vigorously growing isolates were near the edge of the petri dish. At each temperature, nine single-conidium cultures of each isolate were assessed in each of four replicates of the experiment, for a total of 36 single-conidium cultures of each isolate. A randomized complete block design was utilized.

Statistical analyses. Pycnidial and conidial morphology. Differences in conidial length, conidial width, pycnidial diameter, and pycnidial neck length were assessed with analysis of variance. For each data set, the assumptions of constant variance and normality were assessed by plotting residuals against predicted values and evaluating their variance and by plotting residuals against their ranks and examining their linearity. In all data sets, the assumptions were met, and no transformations were applied to the data. Single-degree-of-freedom contrasts were performed for all pairwise combinations of isolates; to control the type I error rate at the level of the experiment, the Tukey multiple comparison procedure (26) was employed. Analyses were conducted at both the level of isolate and the level of infraspecific variety (using pooled data from corresponding isolates). Analyses were implemented in PROC GLM of SAS (version 9.2; SAS Institute, Cary, $\mathrm{NC}$ ).

Conidial guttule number and pycnidial neck number were analyzed with cumulative logistic regression (18), and singledegree-of-freedom contrasts of all possible pairwise combinations of isolates or infraspecific varieties were conducted with Wald $\chi^{2}$ tests. Analyses were conducted at both the level of isolate and the level of infraspecific variety (using pooled data from corresponding isolates). Analyses were implemented in PROC GENMOD of SAS (version 9.2; SAS Institute). The Bonferroni multiple comparison procedure (26) was used to control the type I error rate at the level of the experiment across the 528 pairwise contrasts of individual isolates for the in vitro morphology data, 66 pairwise contrasts of individual isolates for the in vivo morphology data, and 21 pairwise contrasts of infraspecific varieties.

Differences in conidial septation across isolates and across infraspecific varieties were evaluated with $\chi^{2}$ tests of independence (41). Pairwise contrasts of isolates and infraspecific varieties were conducted with single-degree-of-freedom $\chi^{2}$ tests, and the Bonferroni multiple comparison procedure (26) was used to control the type I error rate at the level of the experiment.

In vitro growth rates. In vitro growth rates of isolates were evaluated with analysis of variance, and analysis was conducted controlling for the effect of experimental replicate. Single-degreeof-freedom contrasts were performed for all pairwise combinations of isolates; to control the type I error rate at the level of the experiment, the Tukey multiple comparison procedure (26) was employed. Analyses were implemented in PROC GLM of SAS (version 9.2; SAS Institute).

Pathogenicity testing. Root rot severity was analyzed with cumulative logistic regression (18), with analysis conducted controlling for the effect of experimental replicate. Single-degreeof-freedom contrasts between the control and each of the 13 inoculated treatments were conducted with Wald $\chi^{2}$ tests, and the Bonferroni multiple comparison procedure (26) was used to control the type I error rate at the level of the experiment. Analyses were implemented in PROC GENMOD of SAS (version 9.2; SAS Institute).

\section{RESULTS}

Fungal strains. All isolates produced large pycnidia with long necks for spore discharge and generated white cirri that turned yellow with age. Diagnostic PCR resulted in amplicons of the expected size $(\approx 500 \mathrm{bp})$ from 151 of 154 P. sclerotioides isolates evaluated. Diagnostic PCR was repeated for isolates ME 2-6cr, MT 3-3-2a, and NY Wyo1-3r but always failed to produce an amplification product.

Phylogenetic analyses. Alignment and concatenation of ACT, AT, BT, EF1 $\alpha$, G3P, HIS, IGS-NS, IGS-NL, ITS, and NAD sequences of $P$. sclerotioides isolates and a $P$. medicaginis outgroup resulted in a data set with a length of 8,132 characters, of which 539 were parsimony informative. Parsimony analysis generated 445,997 MPTs with 2,481 steps (CI $=0.7864$, RI $=0.9603)$. Likelihood analysis generated a best tree with log-likelihood score of $-23,921.57$. MP and ML analyses placed $P$. sclerotioides isolates into 29 strongly supported clades (bootstrap values $\geq 70 \%$ ), and 22 strongly supported clades were congruent between MP and ML trees (Fig. 1; labeled as uppercase letters to left of bootstrap values). Of the 22 clades, 9 had bootstrap values $\geq 70 \%$ in all MP and ML gene-jackknife analyses (Fig. 2) and were assigned formal clade or subclade designations (Figs. 1 and 2); others lacked support in one or more gene-jackknife analyses. Gene-jackknife and single-gene analyses permit assessment of whether support for individual clades in the full (10-locus) data set is driven by a single locus or by a signal derived from multiple 


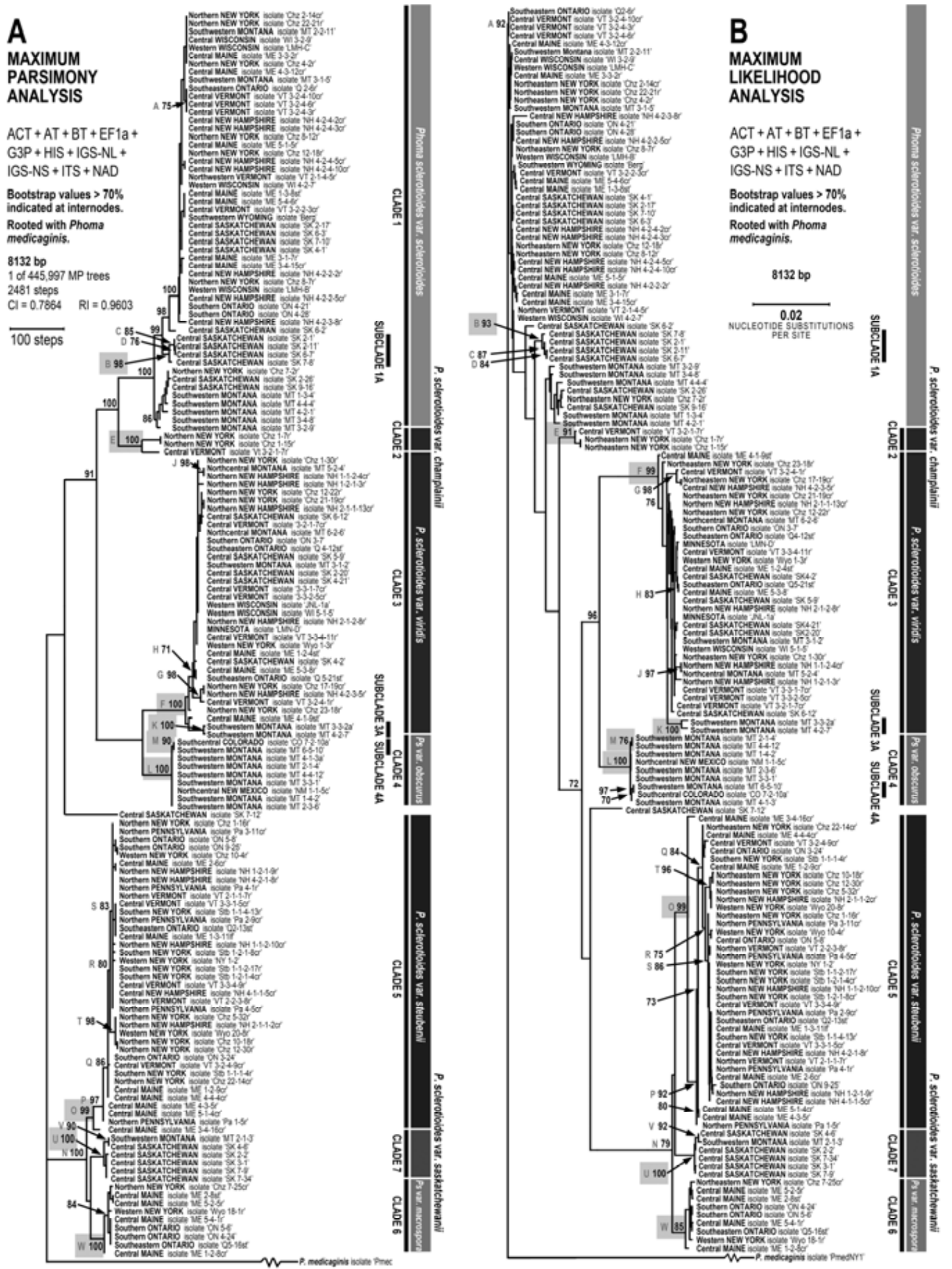

Fig. 1. A, Maximum parsimony (MP) and B, maximum likelihood (ML) $(\mathrm{ln}=-23,921.57)$ analyses of concatenated sequence data from 10 loci. Trees rooted with Phoma medicaginis, and bootstrap values $>70 \%$ (1,000 replications) indicated at nodes. Clades that are congruent in MP and ML analyses are indicated with capital letters to the left of the bootstrap values. Clades that have $>70 \%$ bootstrap support in all MP and ML gene-jackknife analyses are indicated by shading of bootstrap values and associated letters at nodes. 

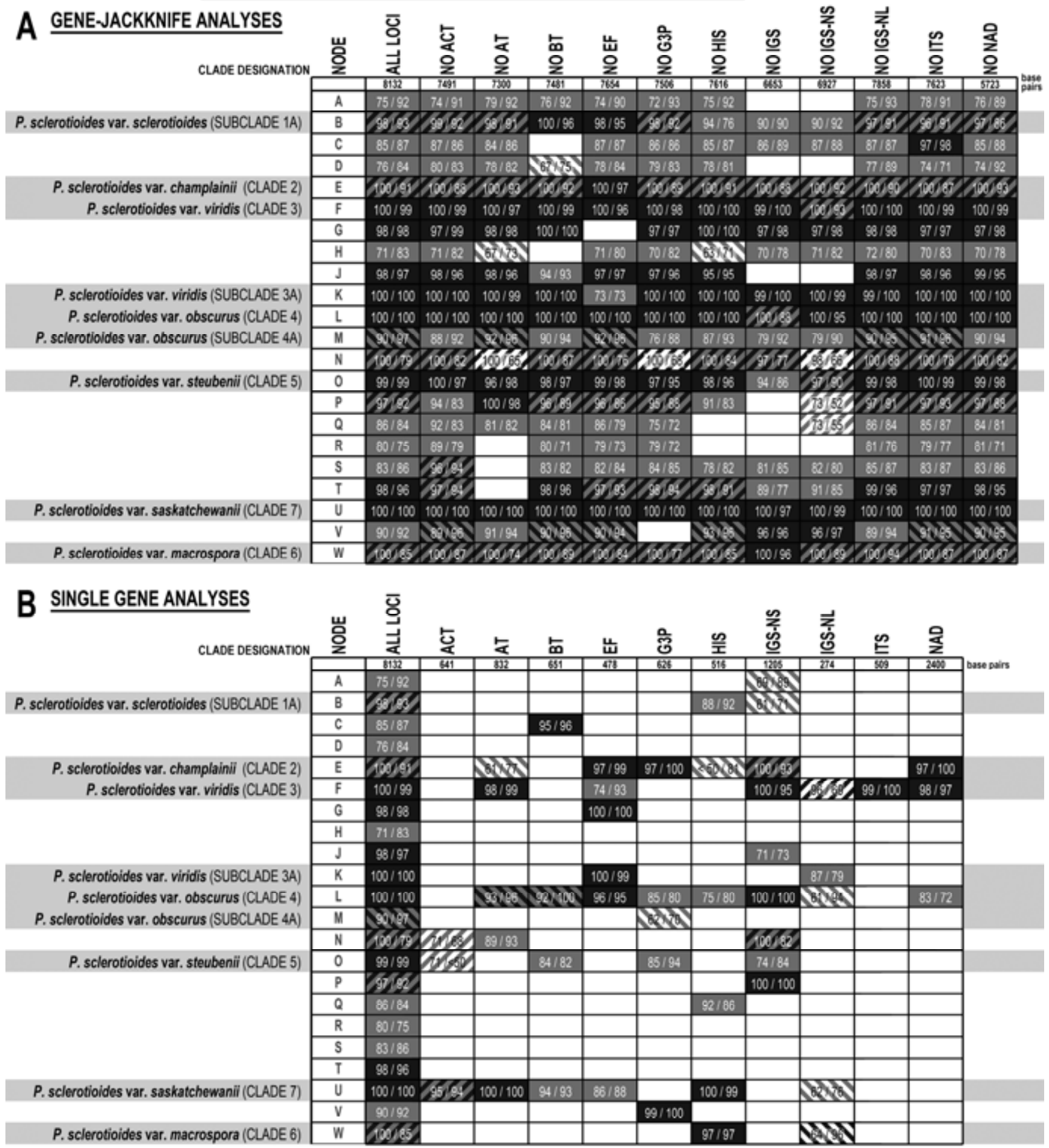

Numbers at left of forward slash: bootstrap values from maximum parsimony analysis

Numbers at right of foward slash: bootstrap values from maximum likelihood analysis

Color Key: $\square$ MP and ML bootstrap values $295 \% \quad 95 \%>$ MP and ML boostrap values $\geq 70 \% \quad \square \quad \square$ MP and ML bootstrap values $<70 \%$

VI MP boostrap value $\geq 95 \%$ and $95 \%>$ ML boostrap value $\geq 70 \%$

MP bootstrap value $\geq 95 \%$ and ML bootstrap value $<70 \%$

MP bootstrap value $\geq 70 \%$ and ML bootstrap value $<70 \%$ ML bootstrap value $\geq 70 \%$ and MP bootstrap value $<70 \%$

Fig. 2. Congruence of clades as determined from maximum parsimony (MP) and maximum likelihood (ML) analyses of A, gene-jackknife and B, single-gene data partitions. Size of each partition is given below its name. Nodes (identified by capital letters) correspond to clades that are congruent in MP and ML analyses of the full 10-locus data set. In each analysis, 1,000 bootstrap replicates were performed. Single-gene analyses that did not provide strong bootstrap support ( $\geq 70 \%)$ for specific infraspecific varieties did not assign the infraspecific varieties to conflicting, strongly supported clades, with two exceptions: MP and ML analyses of the $\alpha$-tubulin (AT) partition, which delineated clade 5 as a paraphyletic group with clade 6 monophyletic within it, and ML analysis of the internal transcribed spacer (ITS) partition, which excluded a single isolate of clade 5 (ME 3-4-16cr) from a node containing isolates of clades 5, 6, and 7 . 
loci. Clades with strong bootstrap support in all gene-jackknifing analyses are robust, with support derived from multiple loci, and strong bootstrap support in multiple single-gene partitions strengthens this conclusion. Of the nine clades with strong bootstrap support in all gene-jackknife analyses, five had bootstrap support $\geq 70 \%$ at four to seven individual loci in MP or ML analyses, and all but one (subclade 4A) (Fig. 2) had bootstrap support $\geq 70 \%$ at two or more individual loci in MP or ML analyses. The nine clades were not assigned to conflicting nodes (bootstrap support $\geq 70 \%$ ) in analyses of single-gene partitions with two exceptions: MP and ML analyses of the AT partition, which delineated clade 5 as a paraphyletic group with clade 6 monophyletic within it, and ML analysis of the ITS partition, which excluded a single isolate of clade 5 (ME 3-4-16cr) from a node containing isolates of clades 5,6 , and 7 . Of the nine clades, formal taxonomic designations were assigned only if at least three representative isolates were morphologically characterized in vitro on PDA, at least one representative isolate was morphologically characterized in vivo on alfalfa, and at least two representative isolates were assessed for their ability to grow at 3,10 , 18 , and $25^{\circ} \mathrm{C}$. Clade 2 was designated $P$. sclerotioides var. champlainii; clade $3, P$. sclerotioides var. viridis; clade $4, P$. sclerotioides var. obscurus; clade 5, $P$. sclerotioides var. steubenii; clade $6, P$. sclerotioides var. macrospora; and clade 7, P. sclerotioides var. saskatchewanii. Subclade 1A (Figs. 1 and 2) falls within a broad group of isolates that is basal to all other isolates in ML analysis and has $100 \%$ bootstrap support in MP analysis (Fig. 1), and it was treated as a subclade of the broader group. This broad group of isolates was designated $P$. sclerotioides var. sclerotioides; it includes $P$. sclerotioides isolate WyoBerg (American Type Culture Collection [ATCC] MYA-295) from Wyoming (Fig. 1) characterized in previous studies $(12,15)$, and sequence identity at the ITS and G3P loci (20) (GenBank accession numbers DQ525737 and DQ525733) suggests that it also contains P. sclerotioides reference isolate CBS 148.84 (ATCC 56515) from British Columbia, Canada. Subclades $3 \mathrm{~A}$ and $4 \mathrm{~A}$, the two remaining clades with strong support in all gene jack-knifing analyses, form subclades of $P$. sclerotioides var. viridis and var. obscurus (Fig. 1). Insufficient morphological characterization of representative isolates precluded the assignment of formal names to subclades 1A, 3A, or 4A. KH and WS-R tests indicated that the MP and ML trees were not congruent $(P<0.0001)$, and both trees are presented (Fig. 3). Infraspecific varieties champlainii, steubenii, and saskatchewanii were named for New York and Vermont's Champlain Valley, New York's Steuben County, and the Canadian province of Saskatchewan, respectively. Infraspecific varieties viridis, obscurus, and macrospora were named for morphological characteristics (green-pigmented mycelium on PDA, dark pigmented mycelium on PDA, and large spores, respectively).

Alignment of ITS sequences for P. sclerotioides, other Phoma spp., and related genera resulted in a data set 517 characters long, of which 215 were parsimony informative. Phylogenetic analysis by MP generated 3,695 MPTs with 1,232 steps $(\mathrm{CI}=0.4513, \mathrm{RI}=$ 0.8781 ). Phylogenetic analysis by ML generated a best tree with log-likelihood score $-5,913.94$. In both MP and ML analyses, all $P$. sclerotioides isolates were placed in a strongly supported monophyletic group with L. doliolum (Fig. 3; bootstrap support $\geq 98 \%$ ), and $P$. sclerotioides and L. doliolum (anamorph $P$. acuta) were grouped with other members of Phoma section Plenodomus. Section Plenodomus, the division within Phoma in which $P$. sclerotioides is placed on the basis of morphological characteristics, is associated with thick scleroplectenchymatous pycnidial walls, glabrous pycnidia, one- to two-celled conidia, and, when known, a Leptosphaeria teleomorph (8). KH and WS-R tests indicated that the MP and ML trees were not congruent $(P<$ 0.0001), and both trees are presented (Fig. 3).

In vivo morphology. The pycnidial morphology of all isolates was consistent with the species description (8). Pycnidia were glabrous, subglobose, and superficial (Fig. 4). Pycnidia were composed of outer polygonal cells with thick, scleroplectenchymatous cell walls that overlay thin-walled, smaller, polygonal cells in the interior (Fig. 5). In mature pycnidia, the thinwalled cells in the interior gave rise to conidiogenous cells. Cells at the central base of pycnidia were scleroplectenchymatous and either polygonal or elongated, forming a pallisade. Pycnidial diameters fell within the range of species description ([200- ]350$800[-1,000] \mu \mathrm{m})(8)$ but only isolates of $P$. sclerotioides var. sclerotioides and champlainii produced pycnidia with diameters $\leq 1,000 \mu \mathrm{m}$. Isolates of other varieties of $P$. sclerotioides exhibited maximum diameters of 600 to $800 \mu \mathrm{m}$ but considerable isolate-isolate variability existed within varieties (Fig. 6). Pycnidia of all isolates produced long necks for spore discharge, with maximum neck lengths of 500 to $800 \mu \mathrm{m}$ (Figs. 4 and 6), but $P$. sclerotioides var. champlainii isolate NY Chz1-7r produced significantly longer necks than the others $(P<0.01)$ (Fig. $6)$. Pycnidia with multiple necks were common in all isolates but were most common in isolates of $P$. sclerotioides var. sclerotioides, champlainii, and obscurus (Fig. 6). Pycnidial necks of $P$. sclerotioides var. sclerotioides and viridis isolates were glabrous to semipilose; pycnidial necks of $P$. sclerotioides var. champlainii isolate NY Chz1-7r were glabrous to pilose; and pycnidial necks of $P$. sclerotioides var. obscurus, steubenii, macrospora, and saskatchewanii isolates were semipilose to pilose (Fig. 4). All isolates produced cream-colored cirrus that yellowed with age.

Conidial morphology of isolates approximated the species description (8) with a few exceptions. No eguttalate conidia were observed, conidia were not always aseptate, and conidial lengths were more variable. Conidia were hyaline and subcylindrical to ellipsoidal, with one to three guttules in P. sclerotioides var. champlainii, steubenii, and saskatchewanii and one to four guttules in all others (Fig. 7). Guttules were mostly polar. P. sclerotioides var. macrospora produced both one- and two-celled conidia, and others produced only aseptate conidia. Conidial lengths were highly variable. All varieties of $P$. sclerotioides produced a range of conidial lengths that partially overlapped the species description but none corresponded to the species description completely. $P$. sclerotioides var. sclerotioides and champlainii produced short conidia (3.5 to $5.6 \mu \mathrm{m})$, P. sclerotioides var. obscurus and macrospora produced long conidia $(4.3$ to $8.1 \mu \mathrm{m})$, and others were intermediate. $P$. sclerotioides var. sclerotioides produced significantly shorter conidia than the others $(P<0.01)$ (Fig. 7). Conidial widths were broadly consistent with the species description (1.5 to $3.0 \mu \mathrm{m}$ ) for all varieties of $P$. sclerotioides except $P$. sclerotioides var. champlainii, in which less variability in conidial widths $(1.4$ to $1.9 \mu \mathrm{m})$ was observed. Conidia of $P$. sclerotioides var. champlainii were significantly narrower than conidia of other varieties $(P<0.01)$ (Fig. 7).

In vitro morphology. Cultural morphology of isolates varied widely on PDA. At $10^{\circ} \mathrm{C}$ under continuous white fluorescent light, aerial mycelium of $P$. sclerotioides var. sclerotioides isolates was sparse and white; aerial mycelium of var. champlainii isolates was sparse to moderately abundant and white; aerial mycelium of var. viridis isolates was moderately abundant to abundant and green to green-gray; aerial mycelium of var. obscurus isolates was moderately abundant to abundant and green-gray to dark gray; and aerial mycelium of varieties steubenii, macrospora, and saskatchewanii was sparse to moderately abundant and tan, brown, or gray (Fig. 4). Isolates of P. sclerotioides var. steubenii, macrospora, and saskatchewanii deposited a tan to yellow-brown pigmentation in the agar surrounding cultures (Fig. 4). Other isolates did not appreciably change the pigmentation of the surrounding agar. In mature cultures, deposition of a dark band of mycelium within the agar at the growing edge of the culture near petri dish walls frequently occurred but was particularly pronounced in isolates of $P$. sclerotioides var. sclerotioides and 


\section{A \\ MAXIMUM PARSIMONY ANALYSIS}

ITS

Bootstrap values $>70 \%$ indicated at internodes.

Rooted with Saccharomyces cerevisiae

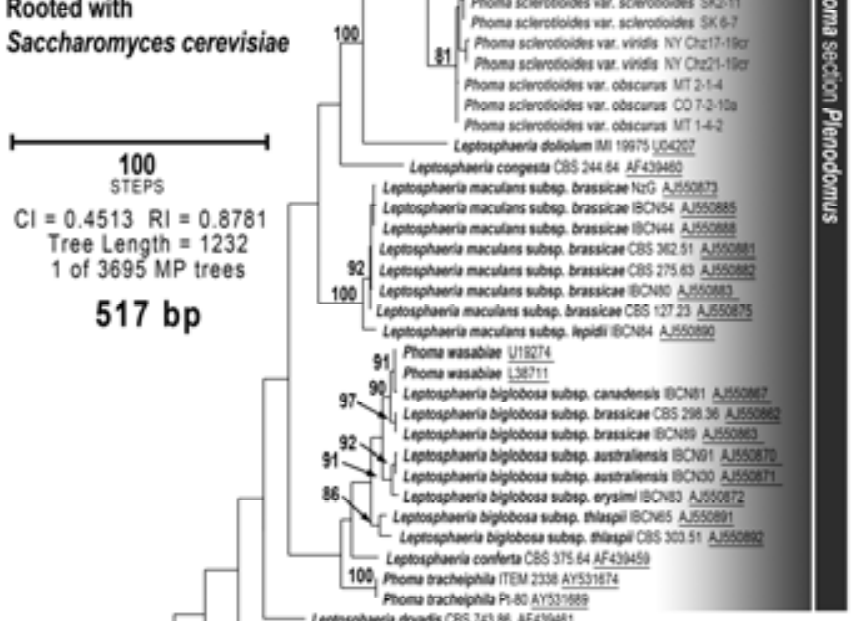

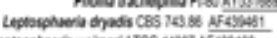

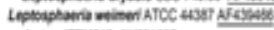

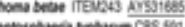

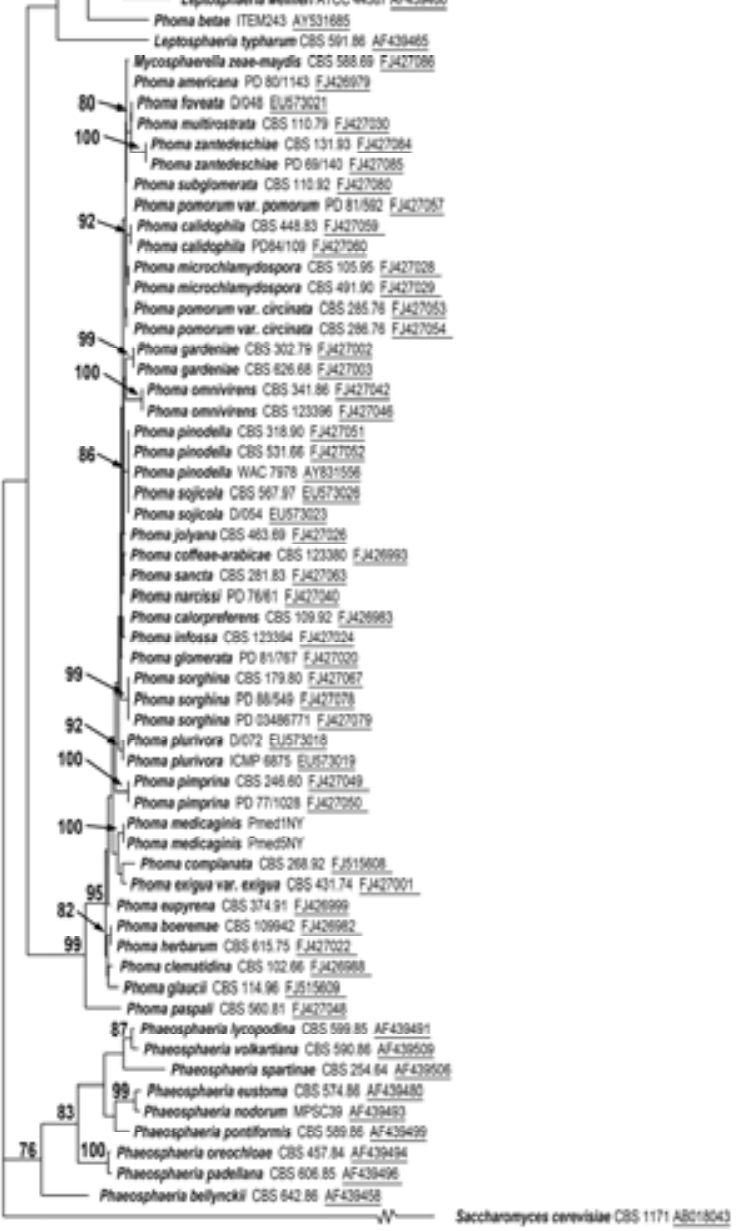

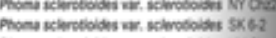

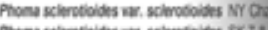

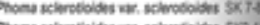

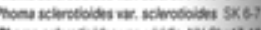
(n)
B

MAXIMUM LIKELIHOOD ANALYSIS

ITS

Bootstrap values $>70 \%$ indicated at internodes.

Rooted with Saccharomyces cerevisiae
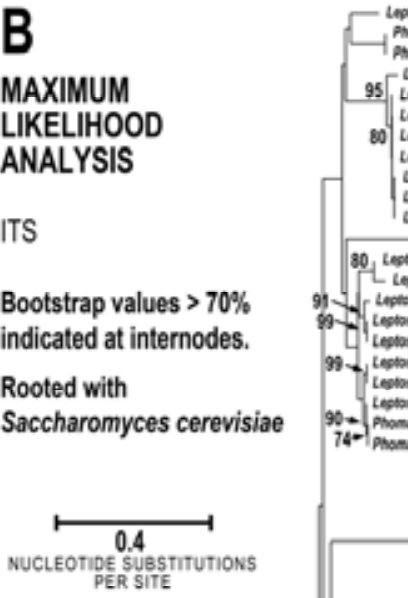

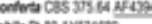

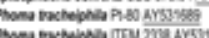

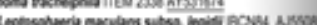

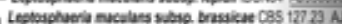

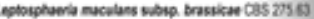

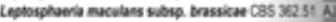

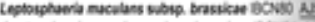

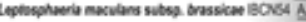

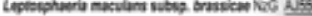

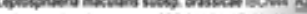

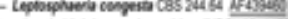

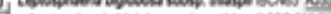

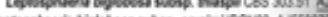
NUCLEOTIDE SUBSTITUTIONS
PER SITE

517 bp

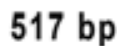

$n$

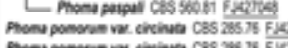

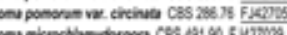

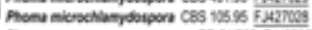

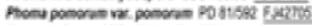

Phone intorsa Cas 123094 FMazrees

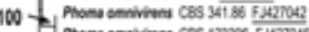

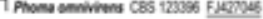

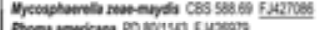

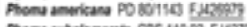

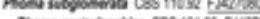

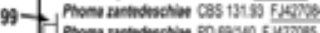

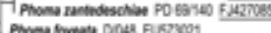

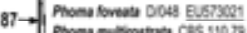

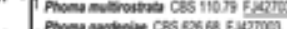

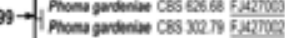

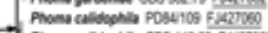

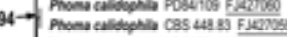

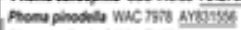

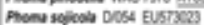

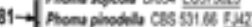

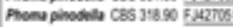

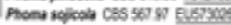

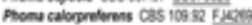

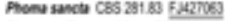

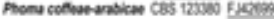

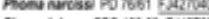

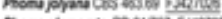
Phon planend po

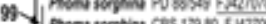

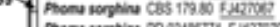

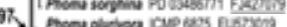

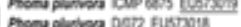

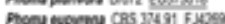

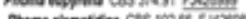

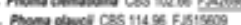

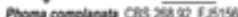

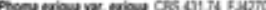
Phome medicaging Prestesy 100 - Ti Phome modcaginis Predis

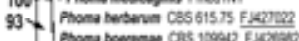

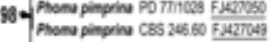

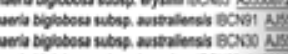

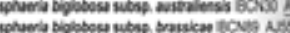

.

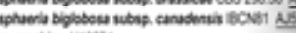

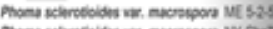

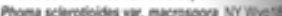

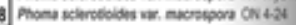

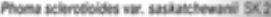

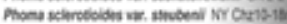

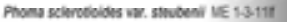

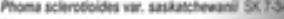

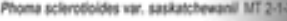

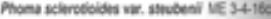

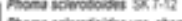

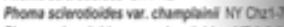

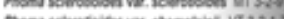

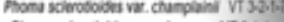

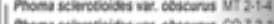

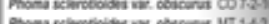

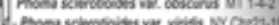

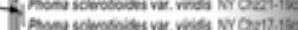

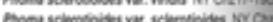

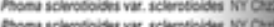

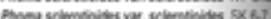

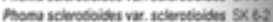

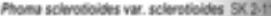

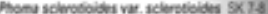

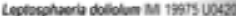

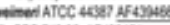

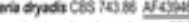

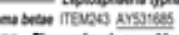

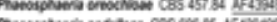

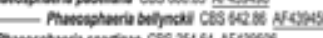

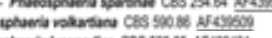

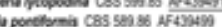

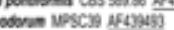$$
\text { (1) }
$$ 


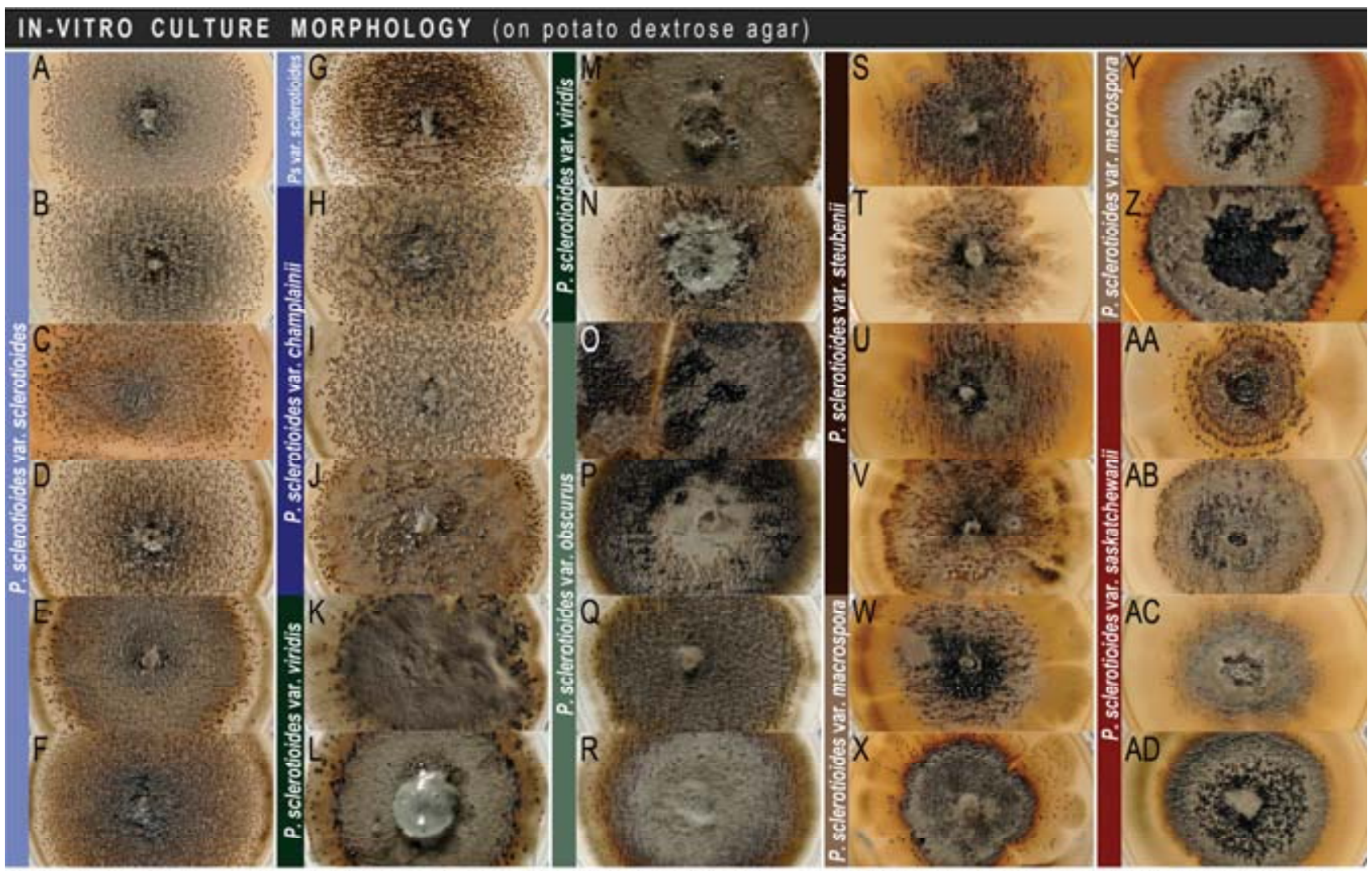

A.G: P. sclerotioides var. sclerotioides isolates 'NY Chz2-14c' (A), 'MT 3-1-5' (B), 'ON 4-28st' (C), 'SK 2-11' (D), 'SK 7-8' (E), 'NY Chz7-2r' (F), 'MT 4-4-4' (G)

H-J: P. sclerotioides var. champlainii isolates $N$ Y Chz1-7r' (H), NY Chz1-15r' (I), VT 3-2-1-7r' (J)'

K-N: P. sclerotioides var. viridis isolates 'NY Chz17-19c' (K), 'SK 4-21' (L), 'WI 5-1-5' (M). 'SK 4-21' (N)

O-R: $P$. sclerotioides var. obscurus isolates 'MT 1-4-2' (0), 'MT 4-1-3a' (P), 'MT 4-4-12' (Q), 'CO 7-2-10a' (R)

S.V: P. sclerotioides var, steubenii isolates 'NY Chz10-18r' (S). VT 2-2-3-8r' (T), 'ME 1-3-111f (U). 'NH 4-2-1-8r' (V)

W.Z: P. sclerotioides var. macrospora isolates 'NY Chz7-25cr' (W), 'ON 5-6' (X). 'ME 5-2-5r' (Y). 'NY Wyo18-1r' (Z)

AA-AD: P. sclerotioides var. saskatchewanii isolates 'SK 7-34' (AA), 'SK 4-6' (AB), 'SK 3-1' (AC), 'MT 2-1-3' (AD)
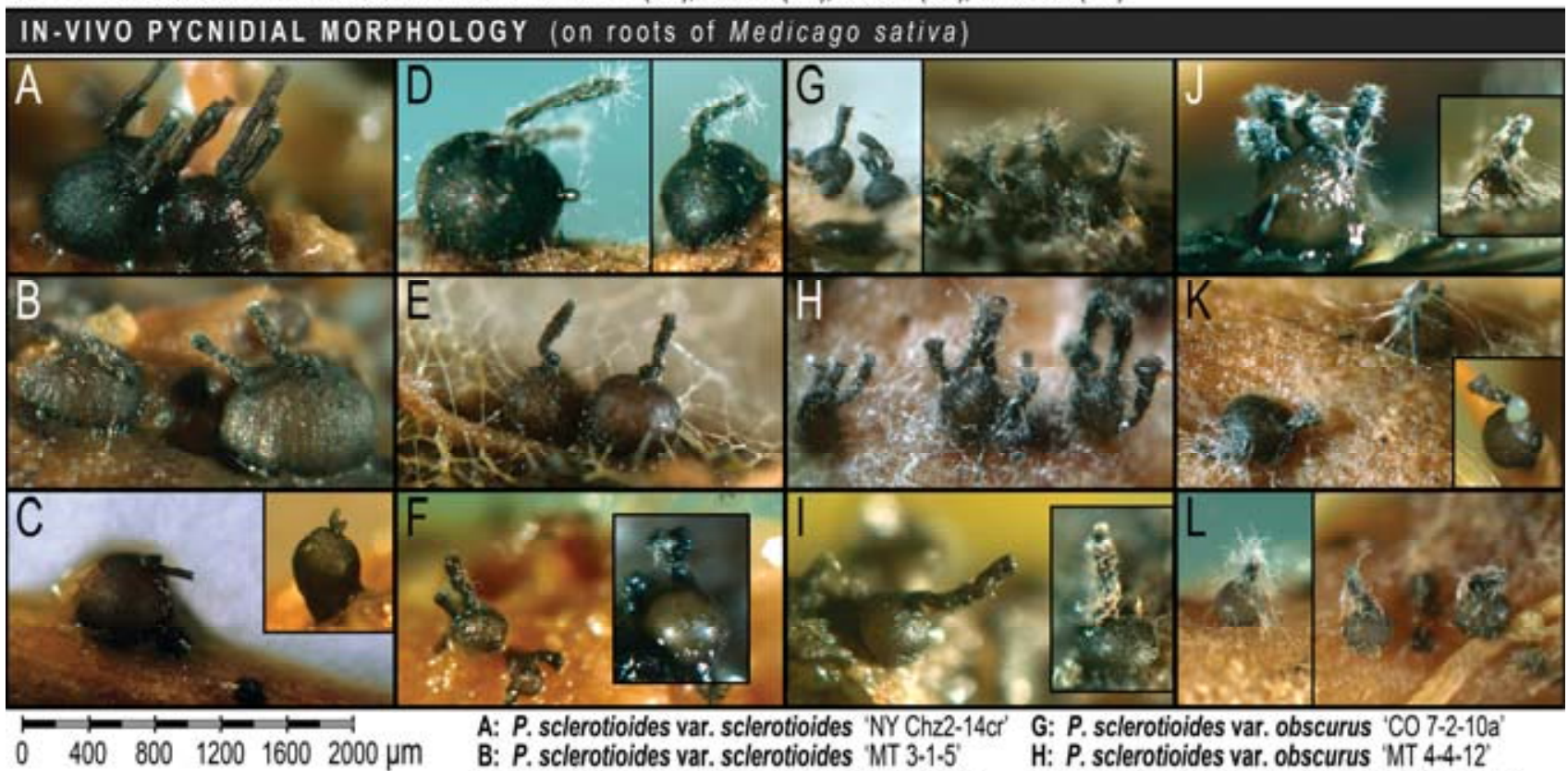
A: P. sclerotioides var. sclerotioides 'NY Chz2-140
C: P. sclerotioides var. sclerotioides 'NY Chz7-2r'
D: P. sclerotioides var. champlainii 'NY Chz1-7r'
E: P. sclerotioides var. viridis 'NY Chz17-19cr'
I: P. sclerotioides var. steubenii 'NY Chz10-18'
F: P. sclerotioides var. viridis 'MT 3-3-2a'
$\mathrm{J}$ : P. sclerotioides var, steubenii 'ME 1-3-11f'
K: P. sclerotioides var. macrospora 'ME 5-2-5r'
L: P. sclerotioides var. saskatchewanii 'MT 2-1-3'

Fig. 4. Images illustrating that infraspecific varieties of Phoma sclerotioides differ morphologically yet produce pycnidia that are consistent with the species description of $P$. sclerotioides (8). In vitro (top), mycelium pigmentation differs by infraspecific variety. In vivo (bottom), all infraspecific varieties produce glabrous or nearly glabrous, subglobose, and superficial pycnidia with long necks for spore discharge. In vitro morphology was assessed by growing singleconidium isolates on potato dextrose agar at $10^{\circ} \mathrm{C}$ under continuous white fluorescent light for 2 months. In vivo morphology was assessed by inoculating healthy alfalfa with single-conidium isolates, harvesting diseased roots, and incubating symptomatic roots in moist chambers until pynidial maturity. 
champlainii (Fig. 4). Differences in culture appearance were repeatable, with isolates consistently showing the same phenotype when started from frozen stocks.

All isolates produced large pycnidia (maximum diameter 600 to $1,350 \mu \mathrm{m}$ ) with long necks for spore discharge. Pycnidial diameters were most variable in isolates of $P$. sclerotioides var. viridis $(270$ to $1,300 \mu \mathrm{m})$ and champlainii $(320$ to $1,350 \mu \mathrm{m})$, least variable in isolates of $P$. sclerotioides var. steubenii (300 to $760 \mu \mathrm{m}$ ), and intermediate (200 or 300 to 900 or $1,100 \mu \mathrm{m}$ ) in the others (Fig. 6). Pycnidial necks were $\approx 150$ to $800 \mu \mathrm{m}$ long, except in isolates of $P$. sclerotioides var. champlainii, which produced significantly longer necks $(280$ to $1,240 \mu \mathrm{m})(P<0.01)$. Pycnidia with multiple necks were produced by all isolates but were most common in isolates of $P$. sclerotioides var. sclerotioides, champlainii, and obscurus (Fig. 6). All isolates produced creamcolored cirrus that yellowed with age.

Conidia were hyaline and subcylindrical to ellipsoidal, with one to four guttules in P. sclerotioides var. champlainii, viridis, and saskatchewanii and one to five guttules in all others (Fig. 7). Guttules were mostly polar. $P$. sclerotioides var. macrospora produced both aseptate and one-septate conidia, and others produced only aseptate conidia. Conidial lengths were highly variable. $P$. sclerotioides var. sclerotioides and champlainii produced short conidia (usually 4 to $7.5 \mu \mathrm{m}$ but sometimes 2.5 to $7.9 \mu \mathrm{m}$ ), $P$. sclerotioides var. macrospora produced long conidia (6 to $12.4 \mu \mathrm{m})$, and others were intermediate. P. sclerotioides var. macrospora produced significantly longer conidia than the others
$(P<0.01)$ (Fig. 7), and $P$. sclerotioides var. sclerotioides and champlainii produced the shortest conidia $(P<0.01)$. Conidia were $\approx 2$ to $4 \mu \mathrm{m}$ wide in $P$. sclerotioides var. viridis, obscurus, steubenii, macrospora, and saskatchewanii but significantly narrower $(1.5$ to $3.2 \mu \mathrm{m})$ in var. champlainii $(P<0.010$ (Fig. 7$)$. Conidial widths of $P$. sclerotioides var. sclerotioides were intermediate between var. champlainii and the others.

Pathogenicity testing. Of 13 isolates, 11 caused significantly more disease on Vernal alfalfa than the control, and at least one isolate of each variety of $P$. sclerotioides caused a significant increase in root rot severity relative to the control (Table 1). The highest levels of root rot severity and plant mortality were associated with isolates of $P$. sclerotioides var. sclerotioides, viridis, and obscurus (Table 1). Lesions were characteristic of BRR: light to dark brown, often with a darker border, and with abundant immature pycnidia produced on the surface of lesions. Root rot severity in the control was very low, suggesting that little cross-contamination occurred across treatments.

In vitro growth. On $\mathrm{PDA}$, isolates grew well at $10^{\circ} \mathrm{C}$ and moderately well at $3^{\circ} \mathrm{C}$ but differed in their growth at 18 and $25^{\circ} \mathrm{C}$. Optimal growth of isolates of $P$. sclerotioides var. macrospora occurred at $10^{\circ} \mathrm{C}$, with growth almost completely inhibited at $25^{\circ} \mathrm{C}$ (Table 2). Isolates of P. sclerotioides var. viridis showed optimal growth at 10 to $18^{\circ} \mathrm{C}$ but also vigorous growth at $25^{\circ} \mathrm{C}$. The temperature adaptation of all other isolates corresponded closely to previous reports $(16,29)$, showing optimal growth at 10 and $18^{\circ} \mathrm{C}$ and limited growth at $25^{\circ} \mathrm{C}$. At $25^{\circ} \mathrm{C}$, isolates of $P$.

\section{IN-VIVO PYCNIDIAL MORPHOLOGY (on roots of Medicago sativa)}

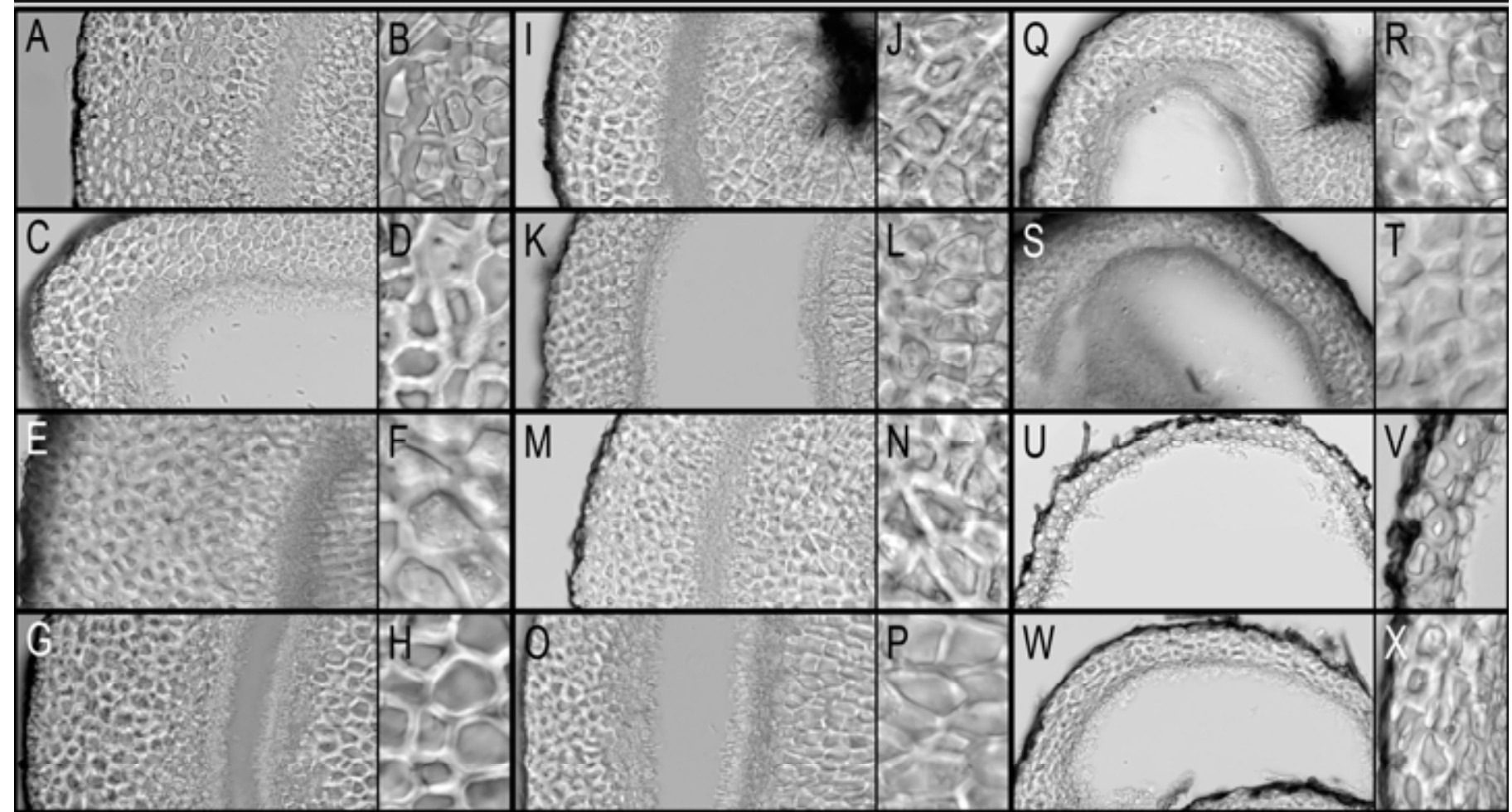

MAIN IMAGES (LEFT)

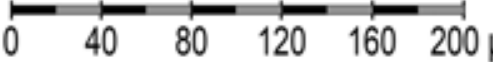

A-B: $P$. sclerotioides var. sclerotioides 'NY Chz2-14
C-D: $P$. sclerotioides var. sclerotioides 'MT $3-1-5$ '

INSET IMAGES (RIGHT):

$\begin{array}{lllllll}0 & 10 & 20 & 30 & 40 & 50 & \mu \mathrm{m}\end{array}$
E-F: P. sclerotioides var. sclerotioides 'NY Chz7-2r'

IN: P. sclerotioides var, viridis 'NY Chz17-19cr'

K-L: P. sclerotioides var. viridis 'MT 3-3-2a'
M-N: P. sclerotioides var. obscurus 'CO 7-2-10a' O-P: P. sclerotioides var. obscurus 'MT 4-4-12' Q-R: P. sclerotioides var. steubenii 'NY Chz10-18r' S-T: $P$. sclerotioides var. steubenii 'ME 1-3-11/f' U-V: P. sclerotioides var. macrospora 'ME 5-2-5r' W-X: P. sclerotioides var. saskatchewanii 'MT 2-1-3'

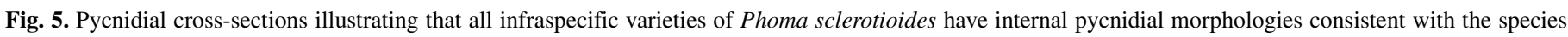

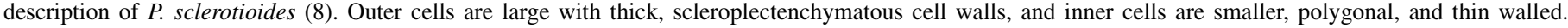

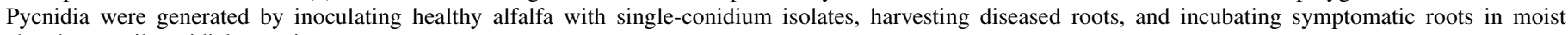
chambers until pynidial maturity. 


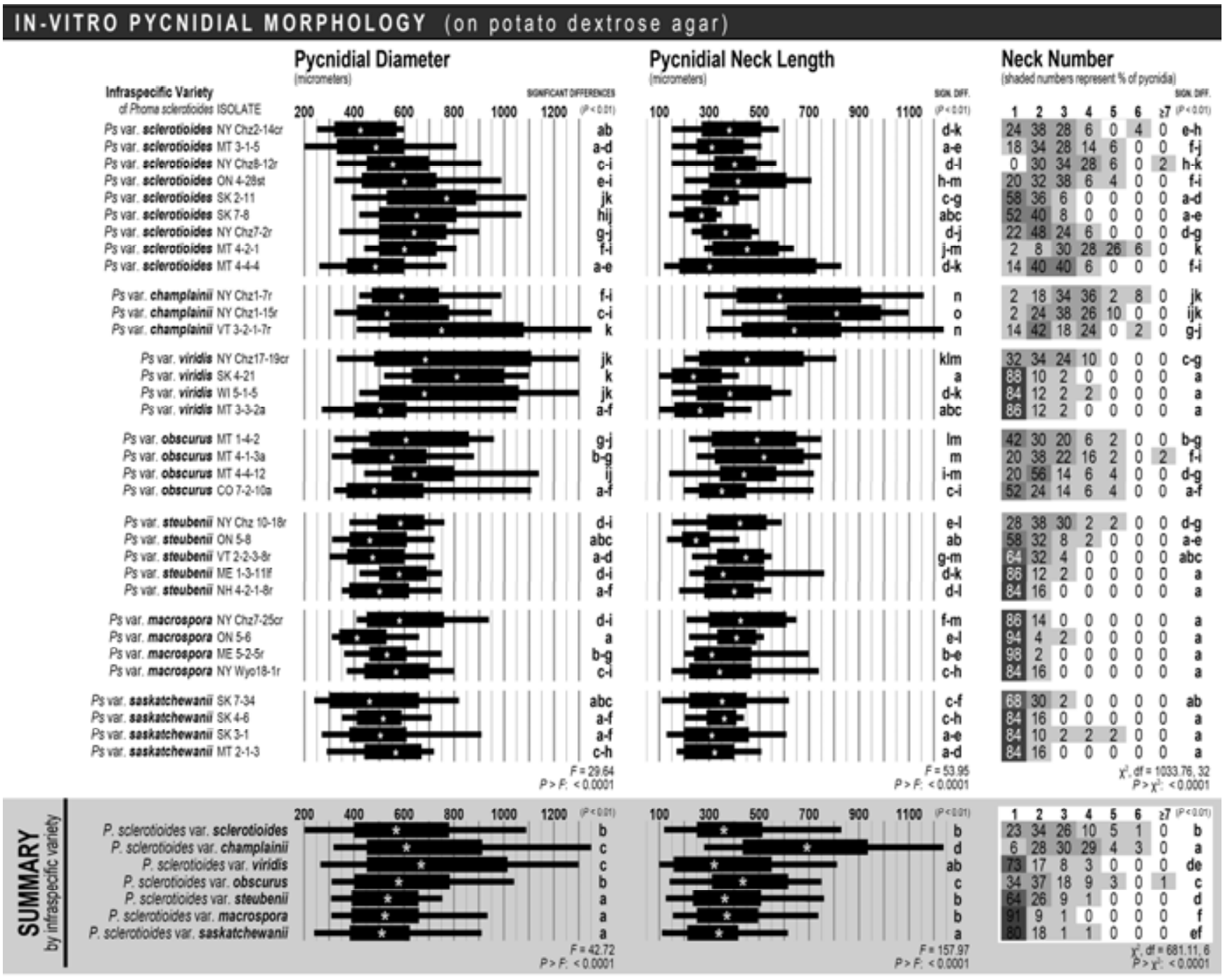

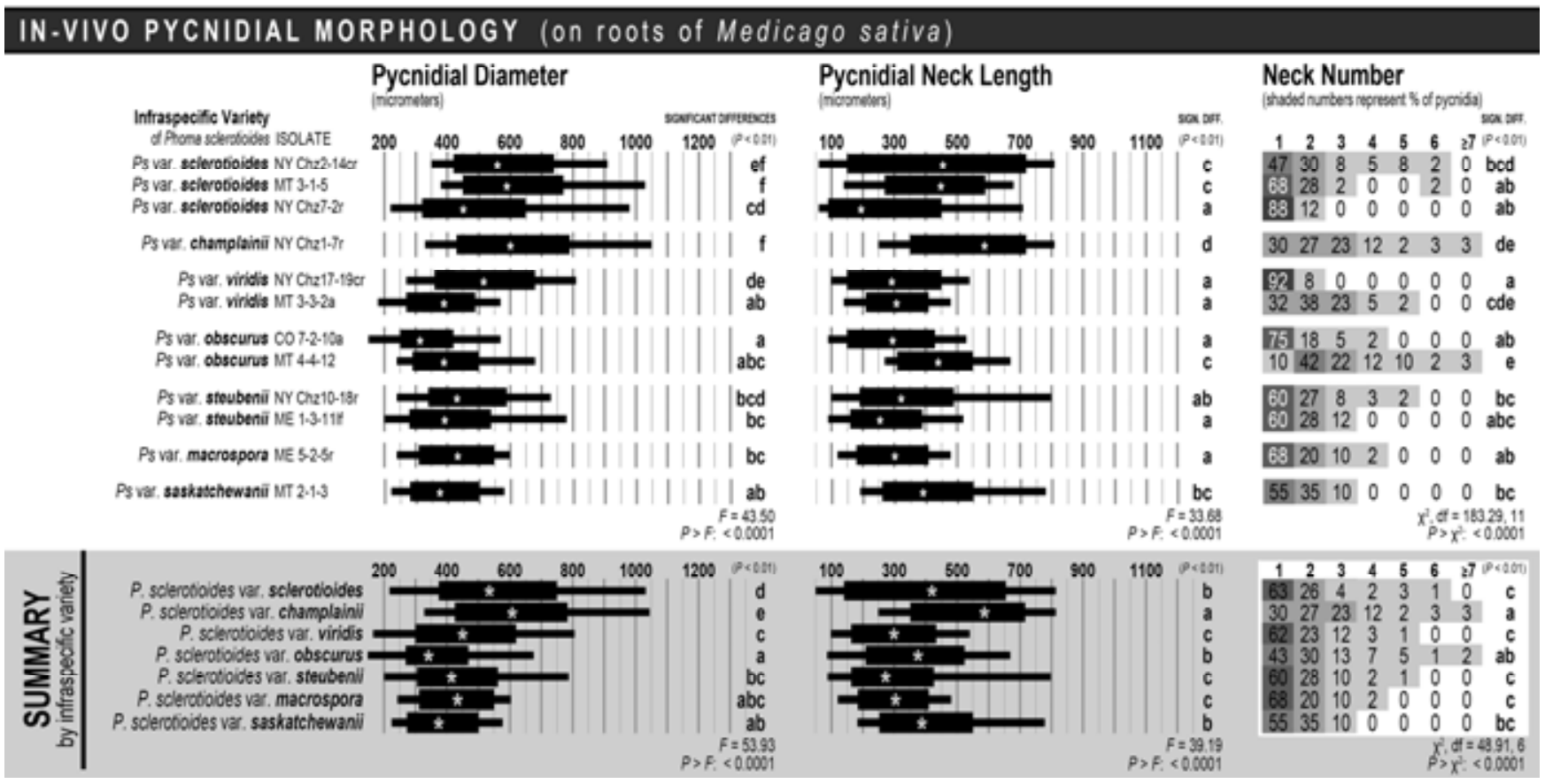

Fig. 6. In vivo and in vitro pycnidial diameters, neck lengths, and neck numbers of Phoma sclerotioides isolates. Thin line of box plots represents the range of data, thick line represents middle $80 \%$ of observations, and asterisk denotes median. Neck number data are given as the percentage of pycnidia observed. Box plots and neck number data followed by different letters are significantly different $(P<0.01)$. The type I error rate was controlled across pairwise comparisons with the Tukey multiple comparison procedure (pycnidial diameter, neck length) or the Bonferroni procedure (neck number). 

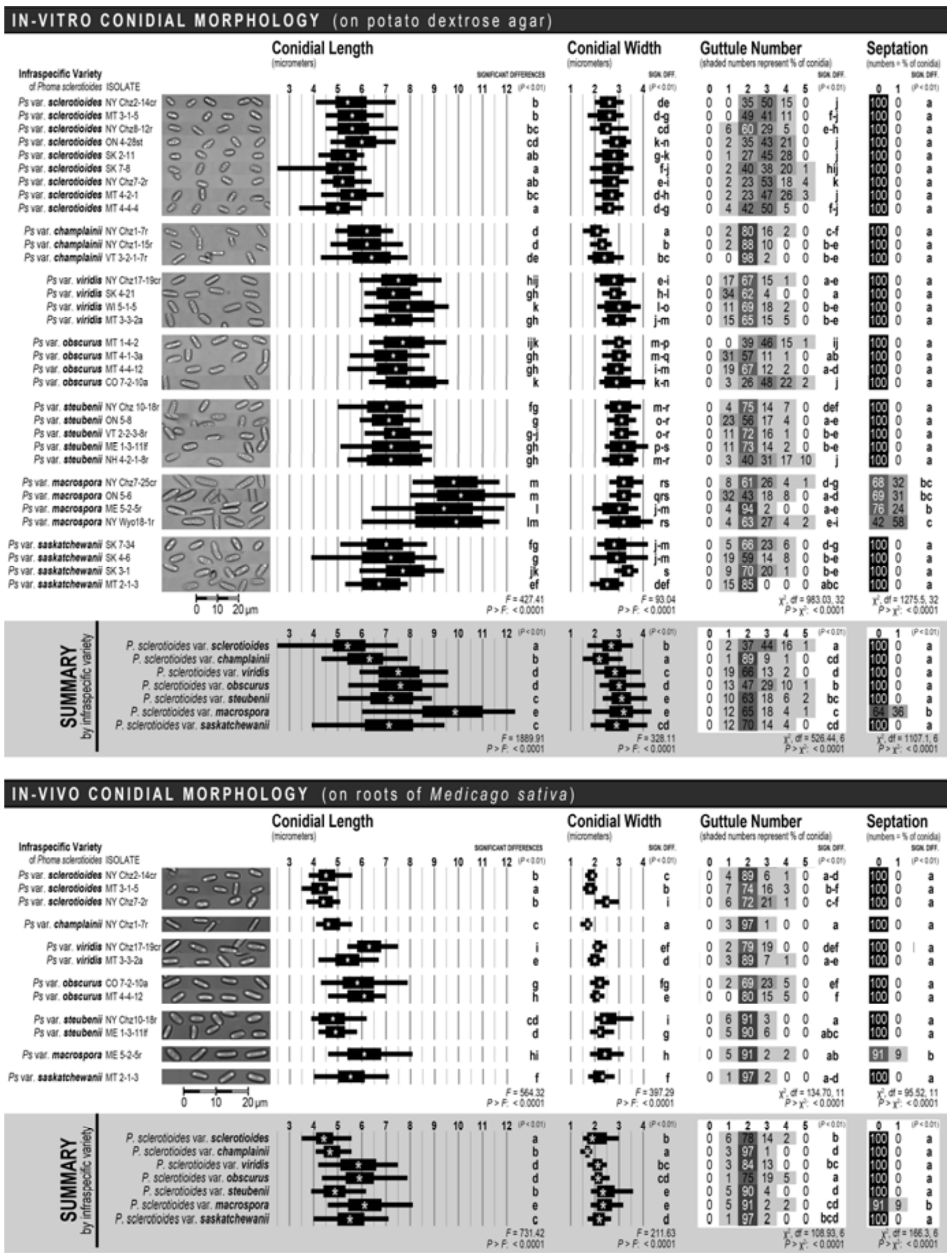

Fig. 7. In vivo and in vitro conidial lengths, widths, guttule numbers, and septation of Phoma sclerotioides isolates. Thin line of box plots represents the range of data, thick line represents middle $80 \%$ of observations, and asterisk denotes median. Guttule number and septation data are given as the percentage of conidia observed. Box plots, guttule number data, and septation data followed by different letters are significantly different $(P<0.01)$. The type I error rate was controlled across pairwise comparisons with the Tukey multiple comparison procedure (conidial length, width) or the Bonferroni procedure (guttule number, septation). 
sclerotioides var. viridis isolates showed significantly more growth than other isolates $(P<0.01)$ (Table 2$)$, and isolates of $P$. sclerotioides var. macrospora showed significantly less growth than all other isolates except ME 1-3-11lf of P. sclerotioides var. steubenii $(P<0.01)$. At 10 and $18^{\circ} \mathrm{C}$, isolates of $P$. sclerotioides var. sclerotioides and champlainii grew significantly more than isolates of $P$. sclerotioides var. obscurus, macrospora, and saskatchewanii $(P<0.01)$ (Table 2) and, at $18^{\circ} \mathrm{C}$, isolates of $P$. sclerotioides var. steubenii were intermediate $(P<0.01)$. At $3^{\circ} \mathrm{C}$, in vitro growth was similar across all varieties of $P$. sclerotioides (Table 2), although moderate but significant $(P<0.01)$ differences were present among individual isolates.

\section{DISCUSSION}

The Phoma isolates evaluated in this study are genetically and morphologically differentiated but all broadly correspond to the published description of $P$. sclerotioides (8). In vivo, they produce glabrous, subglobose, thick-walled pycnidia with scleroplectenchymatous outer cells, thin-walled inner cells, and long necks for spore discharge. Conidia are ellipsoidal to subcylindrical, 1.5 to $3 \mu \mathrm{m}$ wide, and with one to three or one to four mostly polar guttules. All are adapted to low temperatures, and they are pathogenic to alfalfa as it emerges from winter dormancy. Phylogenetic analysis of sequence data from the ITS region places the

TABLE 1. Aggressiveness of Phoma sclerotioides isolates to Vernal alfalfa

\begin{tabular}{|c|c|c|}
\hline Isolate & Plant mortality & Root rot severity ${ }^{\mathrm{z}}$ \\
\hline P. sclerotioides var. sclerotioides NY Chz2-14cr & $9 / 36$ & $3.08 * * * *$ \\
\hline P. sclerotioides var. sclerotioides MT 3-1-5 & $10 / 36$ & $3.83 * * * *$ \\
\hline P. sclerotioides var. sclerotioides NY Chz7-2r & $5 / 36$ & $2.08 * *$ \\
\hline P. sclerotioides var. champlainii NY Chz1-7r & $5 / 36$ & $2.08 * * *$ \\
\hline P. sclerotioides var. viridis NY Chz17-19cr & $10 / 36$ & $3.17 * * * *$ \\
\hline P. sclerotioides var. viridis MT 3-3-2a & $12 / 36$ & $3.44 * * * *$ \\
\hline P. sclerotioides var. obscurus MT 4-4-12 & $11 / 36$ & $2.28 * * * *$ \\
\hline P. sclerotioides var. obscurus $\mathrm{CO} 7-2-10 \mathrm{a}$ & $4 / 36$ & $1.81 * *$ \\
\hline P. sclerotioides var. steubenii NY Chz10-18r & $7 / 36$ & $1.11 \mathrm{NS}$ \\
\hline P. sclerotioides var. steubenii ME 1-3-111f & $1 / 36$ & $0.61 \mathrm{NS}$ \\
\hline P. sclerotioides var. steubenii Fr 1-3-1RC & $3 / 36$ & $1.36 *$ \\
\hline P. sclerotioides var. macrospora ME 5-2-5r & $4 / 36$ & $1.42 *$ \\
\hline P. sclerotioides var. saskatchewanii MT 2-1-3 & $2 / 36$ & $1.36 *$ \\
\hline Control & $1 / 36$ & 0.19 \\
\hline
\end{tabular}

y Proportion of plants dead at conclusion of a replicated experiment conducted on potted alfalfa grown under controlled conditions.

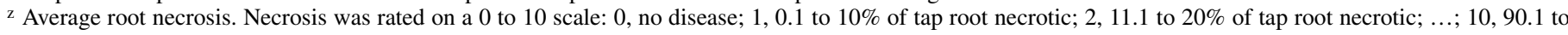
$100 \%$ of tap root necrotic. Asterisks represent significant differences relative to the control: $*, * *, * * *$, and $* * * *$ indicates $P<0.05,0.01,0.001$, and 0.0001 , respectively; NS = not significant. The experiment-wide error rate was controlled with the Bonferonni correction.

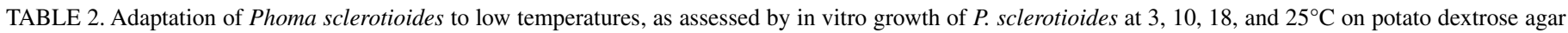
(PDA) 24 days after culture establishment ${ }^{\mathrm{Z}}$

\begin{tabular}{|c|c|c|c|c|}
\hline Isolate & $3^{\circ} \mathrm{C}(\mathrm{mm})$ & $10^{\circ} \mathrm{C}(\mathrm{mm})$ & $18^{\circ} \mathrm{C}(\mathrm{mm})$ & $25^{\circ} \mathrm{C}(\mathrm{mm})$ \\
\hline \multicolumn{5}{|c|}{ P. sclerotioides var. sclerotioides } \\
\hline NY Chz2-14cr & $16.62(2.25)$ defgh & $33.38(1.25) \mathrm{jk}$ & $31.59(1.58) \mathrm{hi}$ & $10.98(1.81) \mathrm{gh}$ \\
\hline MT 3-1-5 & 16.94 (1.91) efghi & $36.22(1.47) 1$ & $36.76(1.37) \mathrm{n}$ & $10.82(1.65) \mathrm{g}$ \\
\hline NY Chz8-12r & 16.85 (1.75) efghi & $34.87(1.61) \mathrm{kl}$ & $34.59(1.46) \mathrm{klm}$ & 12.01 (2.21) ghi \\
\hline NY Chz7-2r & 15.67 (1.69) bcde & $32.90(1.61) \mathrm{ij}$ & $31.00(3.06) \mathrm{gh}$ & $10.76(0.79) \mathrm{g}$ \\
\hline MT 4-4-4 & $14.49(1.59) \mathrm{ab}$ & $31.46(1.03) \mathrm{hi}$ & $29.34(3.29) \mathrm{fg}$ & $3.15(0.55) \mathrm{b}$ \\
\hline SK 2-11 & $15.98(1.44)$ cdef & $33.70(1.43) \mathrm{jk}$ & $35.82(1.92) \mathrm{mn}$ & $5.60(1.14) \mathrm{cd}$ \\
\hline SK 7-8 & 15.39 (1.69) bcd & $30.54(1.15) \mathrm{gh}$ & 32.79 (2.79) hijk & $7.05(0.88) \mathrm{def}$ \\
\hline \multicolumn{5}{|c|}{ P. sclerotioides var. champlainii } \\
\hline NY Chz1-7r & 15.01 (2.07) abc & 30.25 (1.53) fgh & 33.62 (3.61) jkl & $8.28(1.24) \mathrm{f}$ \\
\hline VT $3-2-1-7 r$ & $13.78(1.11) \mathrm{a}$ & $29.54(1.33) \mathrm{fg}$ & 33.01 (1.99) ijk & 7.32 (1.38) def \\
\hline \multicolumn{5}{|c|}{ P. sclerotioides var. viridis } \\
\hline NY Chz17-19cr & $16.27(0.78)$ cdefg & $26.16(1.66) \mathrm{cd}$ & $25.37(2.21) \mathrm{cd}$ & $24.55(1.54) \mathrm{k}$ \\
\hline MT 3-3-2a & $17.25(0.58)$ fghij & $32.06(2.46)$ hij & $35.41(1.90) \mathrm{lmn}$ & $21.06(2.74) \mathrm{j}$ \\
\hline WI 5-1-5 & $18.29(1.00) \mathrm{jk}$ & $28.60(1.13) \mathrm{ef}$ & $32.00(2.14) \mathrm{hij}$ & $25.88(1.28) \mathrm{k}$ \\
\hline \multicolumn{5}{|c|}{ P. sclerotioides var. obscurus } \\
\hline CO 7-2-10a & 17.85 (1.28) hijk & 23.35 (2.70) a & $23.79(2.02) \mathrm{c}$ & $13.42(3.24) \mathrm{i}$ \\
\hline MT 4-4-12 & $17.74(1.63)$ hijk & $26.96(2.47) \mathrm{de}$ & $23.62(2.00) \mathrm{c}$ & $6.04(0.91) \mathrm{cde}$ \\
\hline \multicolumn{5}{|c|}{ P. sclerotioides var. steubenii } \\
\hline NY Chz10-18r & $20.42(1.54) 1$ & $30.3(3.70) \mathrm{fgh}$ & $27.72(1.66) \mathrm{ef}$ & $11.51(2.38) \mathrm{ghi}$ \\
\hline ME 1-3-11lf & 17.89 (1.40) hijk & $30.95(2.67) \mathrm{gh}$ & $27.01(2.02) \mathrm{de}$ & $4.16(3.27) \mathrm{bc}$ \\
\hline NH 4-2-1-8r & $17.37(0.73)$ ghij & $26.48(3.37) \mathrm{cd}$ & $26.88(1.25) \mathrm{de}$ & $6.17(5.64) \mathrm{de}$ \\
\hline \multicolumn{5}{|c|}{ P. sclerotioides var. macrospora } \\
\hline ME 5-2-5r & 18.01 (1.07) ijk & $27.03(1.35) \mathrm{de}$ & $24.28(1.73) \mathrm{c}$ & $2.76(1.46) \mathrm{b}$ \\
\hline NY Wyo18-1r & $18.96(1.87) \mathrm{k}$ & $24.89(2.13) \mathrm{abc}$ & $14.93(2.21) \mathrm{a}$ & $0.27(0.57) \mathrm{a}$ \\
\hline \multicolumn{5}{|c|}{ P. sclerotioides var. saskatchewanii } \\
\hline MT 2-1-3 & $16.10(0.99)$ cdefg & $24.03(2.04) \mathrm{ab}$ & $18.11(2.05) b$ & $12.91(1.17) \mathrm{hi}$ \\
\hline SK 7-34 & $14.95(0.92) \mathrm{abc}$ & $25.63(1.81) \mathrm{bcd}$ & $24.44(1.47) \mathrm{c}$ & $7.73(2.43)$ ef \\
\hline
\end{tabular}

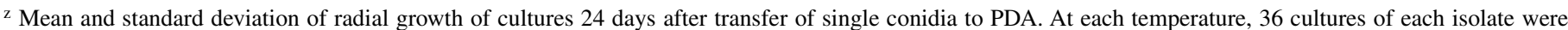
assessed (nine cultures per isolate in each of four replicates). Within temperature treatments, isolates with shared letters are not significantly different $(\alpha=0.01$, experiment-wide error rate controlled with the Tukey multiple comparison procedure). 
isolates in a single monophyletic group, confirming their close relationship.

We propose designating the genetic and morphological variants of $P$. sclerotioides as infraspecific varieties. Within the genus Phoma, there is a long-standing convention of designating morphological variants of anamorph species as varieties of that species rather than independent species. The variety designation is utilized when variants broadly conform to the morphological characteristics of a species but differ in specific traits, such as temperature adaptation, conidial size or septation, culture morphology in vitro, or production of metabolites $(8,34)$. Infraspecific variety designations are common among Phoma spp. $(8,34)$ and variety designations are maintained even when morphological variants are also shown to be genetically differentiated (1). Although infraspecific varieties, not new species, have been designated within P. sclerotioides, the term "species complex" has been retained for describing the seven infraspecific varieties of $P$. sclerotioides as they relate to causing BRR. Consistent with other species complexes, individual BRR lesions can be caused by a single infraspecific variety of $P$. sclerotioides or by a combination of infraspecific varieties.

We have proposed the designation of seven varieties within $P$. sclerotioides, each of which is strongly supported by phylogenetic analyses of multilocus sequence data. The clades corresponding to the infraspecific varieties have strong bootstrap support in MP and ML analyses of a 10-locus sequence data set, and phylogenetic gene-jackknife analyses indicate that this support is driven by a signal across the genome and not by individual loci. Bootstrap support for the infraspecific varieties is also strong in phylogenetic analyses of many single gene partitions and, with only minor exceptions, analyses of single gene partitions did not place isolates of the infraspecific varieties into conflicting clades with strong bootstrap support. Genetic differences among infraspecific varieties correspond to differences in temperature adaptation and morphology. Culture morphology on PDA, pycnidial neck length, conidial length, conidial width, and conidial septation are the most reliable morphological characteristics for delimitation of the varieties. P. sclerotioides var. sclerotioides and champlainii produce short conidia and have white aerial mycelium on PDA; P. sclerotioides var. champlainii produces narrow conidia and very long necks for spore discharge; $P$. sclerotioides var. viridis produces green aerial mycelium on PDA and grows well at $25^{\circ} \mathrm{C} ; P$. sclerotioides var. obscurus produces dark aerial mycelium on PDA; P. sclerotioides var. steubenii, macrospora, and saskatchewanii produce tan, brown, or gray aerial mycelium on PDA and cause the surrounding agar to turn tan or yellow-brown; P. sclerotioides var. steubenii grows more rapidly at 18 and $25^{\circ} \mathrm{C}$ than var. macrospora; and $P$. sclerotioides var. macrospora produces very long conidia, some of which are one-septate, and its growth is nearly completely inhibited at $25^{\circ} \mathrm{C}$.

The designation of additional varieties of $P$. sclerotioides may be warranted in the future. Phylogenetic analyses indicate the existence of at least four additional genetically distinct subtypes of $P$. sclerotioides, one distinct from the seven proposed varieties of $P$. sclerotioides and three within those varieties. One isolate, SK 7-12, was closely related to other $P$. sclerotioides isolates (Figs. 1 and 3) yet genetically too differentiated to be placed within any of the proposed varieties (Fig. 1); and P. sclerotioides var. sclerotioides, viridis, and obscurus each contain robust, strongly supported subclades (Fig. 1; designated 1a, 3a, and 4a). Variety designations were not assigned to these genetically differentiated subtypes because of limited or incomplete characterization. Evaluation of additional isolates from Saskatchewan is required to evaluate the placement of isolate SK 7-12; in vivo morphological characterization of isolates of subclade 1a was not possible due to permit restrictions on the use of Canadian isolates; and morphological characterization of subclades $3 \mathrm{a}$ and $4 \mathrm{a}$ was conducted using only a single isolate from each, thereby precluding an assessment of isolate-isolate variability.

We have chosen to designate the morphologically and genetically distinct subtypes of $P$. sclerotioides as varieties rather than independent species out of recognition of the subtlety of their morphological differences. In vivo on symptomatic alfalfa, many of the subtypes cannot be readily differentiated; even where statistically significant differences exist, considerable overlap in morphological characteristics is found. Differentiation of the subtypes requires either sequencing at informative loci or conducting a combination of in vitro culturing at $10^{\circ} \mathrm{C}$, measurement and assessment of large numbers of conidia and pycnidia, and in vitro growth assays at 18 and $25^{\circ} \mathrm{C}$. Maintenance of a broad species concept for $P$. sclerotioides will facilitate ready identification of the pathogen and minimize confusion associated with improperly identified isolates. Designation of the subtypes as varieties is also consistent with prior precedent in the genus Phoma $(7,9,13,33)$. A multiplex diagnostic PCR protocol is under development to facilitate accurate diagnosis of P. sclerotioides; the diagnostic primers currently available for P. sclerotioides (23) occasionally give false negative results and do not distinguish among intraspecific varieties.

The current study provides a framework for investigating differences in agriculturally significant properties of $P$. sclerotioides isolates. In other diseases caused by Phoma spp., genetic differentiation of isolates has been associated with differences in pathogen aggressiveness, disease symptomology, and the timing of disease onset $(20,30)$. Previous research suggests that isolates of $P$. sclerotioides vary in their aggressiveness to alfalfa (12), and this study indicates that infraspecific varieties of $P$. sclerotioides differ in their temperature adaptation. Research is currently in progress to evaluate whether infraspecific varieties of $P$. sclerotioides differ in their aggressiveness to alfalfa roots and crowns, assess whether differences in aggressiveness depend on alfalfa genotype, and evaluate how the composition of the $P$. sclerotioides species complex differs across North America. P. sclerotioides can also contribute to spring black stem and leaf spot of alfalfa (36) and infect roots of overwintering grasses $(11,21)$, and research is also in progress to evaluate which components of the $P$. sclerotioides species complex infect roots of overwintering grasses and contribute to foliar disease on alfalfa. Because variation within $P$. sclerotioides in aggressiveness, host range, geographic distribution, and temperature adaptation could influence alfalfa breeding strategies and crop rotations, the current study provides a framework for investigating the improved management of BRR.

The following descriptions are proposed for the varieties of $P$. sclerotioides. All isolates identified as representative cultures have been deposited in the University of Minnesota Mycological Culture Collection (University of Minnesota Herbarium) as a resource to alfalfa breeders, pathologists, and other researchers.

P. sclerotioides Preuss ex Sacc. var. sclerotioides. In radices M. sativae, conidia eseptata, (3.5-)4-5(-5.6) $\times 1.5-2.7(-3.0) \mu \mathrm{m}$. Colla pycnidii vel una vel numerosa, vel glabra vel paullo pilosa; in longitudinem (120-)200-600(-830) $\mu \mathrm{m}$. In agara solani et sacchari, mycelia aeria alba et sparsa; conidia eseptata, (2.5-)4.5$6.5(-7.5) \times(1.7-) 2-3.5 \mu \mathrm{m}$. Colla pycnidii vel una vel numerosa, in longitudinem (120-)200-600(-830) $\mu \mathrm{m}$. Aput $18^{\circ} \mathrm{C}$, auctus medius coloniae 29 ad $37 \mathrm{~mm}$ post 24 dies. Aput $25^{\circ} \mathrm{C}$, auctus medius coloniae 3 ad $12 \mathrm{~mm}$ post 24 dies.

Differentiating characteristics. In vivo (alfalfa roots): Conidia aseptate, $(3.5-) 4-5(-5.6) \times 1.5-2.7(-3.0) \mu \mathrm{m}$ with one to four guttules. Pycnidial necks glabrous to semipilose, single or multiple, with lengths up to $(50-) 100-700(-800) \mu \mathrm{m}$.

In vitro (PDA): Under continuous light at $10^{\circ} \mathrm{C}$, aerial mycelium white and sparse. Conidia aspetate, (2.5-)4.5-6.5(-7.5) $\times$ (1.7-)2-3.5 $\mu \mathrm{m}$ with one to five guttules. Pycnidial necks up to (120-)200-600(-830) $\mu \mathrm{m}$ long and frequently multiple. After 
24 days in complete darkness at 18 and $25^{\circ} \mathrm{C}$, average radial growth 29 to $37 \mathrm{~mm}$ and 3 to $12 \mathrm{~mm}$, respectively.

Representative cultures. NY Chz2-14cr ex $M$. sativa (Leguminaceae), New York, United States; NY Chz7-2r ex $M$. sativa (Leguminaceae), New York, United States; and SK 7-8 ex M. sativa (Leguminaceae), Saskatchewan, Canada.

P. sclerotioides var. champlainii Wunsch \& Bergstrom, var. nov. In radices $M$. sativae, conidia eseptata, 4-5.6 × 1.4-1.9 $\mu \mathrm{m}$. Colla pycnidii plerumque numerosa, vel glabra vel pilosa; in longitudinem (250-)350-720(-810) $\mu \mathrm{m}$. In agara solani et sacchari, mycelia aeria alba et sparsa vel paullo abunda; conidia eseptata, (4.3-)5.4-7.2(-7.9) $\times(1.5-) 1.8-2.8(-3.2) \mu \mathrm{m}$. Colla pycnidii plerumque numerosa, in longitudinem (300-)400$1,000(-1,100) \mu \mathrm{m}$. Aput $18^{\circ} \mathrm{C}$, auctus medius coloniae 33 ad $34 \mathrm{~mm}$ post 24 dies. Aput $25^{\circ} \mathrm{C}$, auctus medius coloniae 7 ad $8 \mathrm{~mm}$ post 24 dies.

Differentiating characteristics. In vivo (alfalfa roots): Conidia aseptate, $4-5.6 \times 1.4-1.9 \mu \mathrm{m}$. Pycnidial necks glabrous to pilose, usually multiple, with lengths up to (250-)350-720(-810) $\mu \mathrm{m}$.

In vitro (PDA): Under continuous light at $10^{\circ} \mathrm{C}$, aerial mycelium white and sparse to moderately abundant. Conidia aspetate, (4.3-)5.4-7.2(-7.9) × (1.5-)1.8-2.8(-3.2) $\mu \mathrm{m}$. Pycnidial necks up to (300-)400-1,000(-1,100) $\mu \mathrm{m}$ long and usually multiple. After 24 days in complete darkness at 18 and $25^{\circ} \mathrm{C}$, average radial growth 33 to $34 \mathrm{~mm}$ and 7 to $8 \mathrm{~mm}$, respectively.

Representative culture. NY Chz1-7r ex M. sativa (Leguminaceae), New York, United States.

P. sclerotioides var. viridis Wunsch \& Bergstrom, var. nov. In radices $M$. sativae, conidia eseptata, (4.2-)4.9-6.8(-7.5) $\times 1.7-$ $2.5 \mu \mathrm{m}$. Colla pycnidii vel una vel numerosa, vel glabra vel paullo pilosa; in longitudinem (100-)150-450(-540) $\mu \mathrm{m}$. In agara solani et sacchari, mycelia aeria viride et abunda vel paullo abunda; conidia eseptata, (5.9-)6.5-9.0(-9.6) × (2.0-)2.2-3.5(-3.9) $\mu \mathrm{m}$. Colla pycnidii vel una vel numerosa, in longitudinem (100-)150$680(-800) \mu \mathrm{m}$. Aput $18^{\circ} \mathrm{C}$, auctus medius coloniae 25 ad $35 \mathrm{~mm}$ post 24 dies. Aput $25^{\circ} \mathrm{C}$, auctus medius coloniae 21 ad $26 \mathrm{~mm}$ post 24 dies.

Differentiating characteristics. In vivo (alfalfa roots): Conidia aseptate, (4.2-)4.9-6.8(-7.5) $\times 1.7-2.5 \mu \mathrm{m}$. Pycnidial necks glabrous to semipilose, single or multiple, with lengths up to (100-)150-450(-540) $\mu \mathrm{m}$.

In vitro (PDA): Under continuous light at $10^{\circ} \mathrm{C}$, aerial mycelium green to green-gray and moderately abundant to abundant. Conidia aspetate, (5.9-)6.5-9.0(-9.6) × (2.0-)2.2-3.5(-3.9) $\mu \mathrm{m}$. Pycnidial necks single or multiple and up to (100-)150-680 $(-800) \mu \mathrm{m}$ long. After 24 days in complete darkness at 18 and $25^{\circ} \mathrm{C}$, average radial growth 25 to $35 \mathrm{~mm}$ and 21 to $26 \mathrm{~mm}$, respectively.

Representative cultures. NY Chz17-19cr ex M. sativa (Leguminaceae), New York, United States; MT 3-3-2a ex $M$. sativa (Leguminaceae), Montana, United States; WI 5-1-5 ex $M$. sativa (Leguminaceae), Wisconsin, United States.

$P$. sclerotioides var. obscurus Wunsch \& Bergstrom, var. nov. In radices $M$. sativae, conidia eseptata, (4.3-)5.2-6.5(-7.9) $\times 1.8-$ $2.6 \mu \mathrm{m}$. Colla pycnidii vel una vel numerosa, vel paullo pilosa vel pilosa, in longitudinem (90-)150-550(-670) $\mu \mathrm{m}$. In agara solani et sacchari, mycelia aeria obscura et paullo abunda vel abunda; conidia eseptata, $(5.5-) 6.5-9.0(-9.6) \times 2.2-3.5(-4.1) \mu \mathrm{m}$. Colla pycnidii plerumque numerosa, in longitudinem (150-)260-680 $(-750) \mu \mathrm{m}$. Aput $18^{\circ} \mathrm{C}$, auctus medius coloniae $23 \mathrm{ad} 24 \mathrm{~mm}$ post 24 dies. Aput $25^{\circ} \mathrm{C}$, auctus medius coloniae 6 ad $13 \mathrm{~mm}$ post 24 dies.

Differentiating characteristics. In vivo (alfalfa roots): Conidia aseptate, (4.3-)5.2-6.5(-7.9) $\times 1.8-2.6 \mu \mathrm{m}$. Pycnidial necks semipilose to pilose, single or multiple, with lengths up to (90-)150-550(-670) $\mu \mathrm{m}$.

In vitro (PDA): Under continuous light at $10^{\circ} \mathrm{C}$, aerial mycelium green-gray to dark gray and moderately abundant to abundant. Conidia aspetate, $(5.5-) 6.5-9.0(-9.6) \times 2.2-3.5(-4.1)$ $\mu \mathrm{m}$. Pycnidial necks up to (150-)260-680(-750) $\mu \mathrm{m}$ long and usually multiple. After 24 days in complete darkness at 18 and $25^{\circ} \mathrm{C}$, average radial growth 23 to $24 \mathrm{~mm}$ and 6 to $13 \mathrm{~mm}$, respectively.

Representative cultures. CO 7-2-10a ex M. sativa (Leguminaceae), Colorado, United States; MT 4-4-12 ex M. sativa (Leguminaceae), Montana, United States.

P. sclerotioides var. steubenii Wunsch \& Bergstrom, var. nov. In radices $M$. sativae, conidia eseptata, (3.9-)4.2-5.3(-6.2) $\times$ (1.8-)2.0-2.9(-3.6) $\mu \mathrm{m}$. Colla pycnidii vel una vel numerosa, vel paullo pilosa vel pilosa; in longitudinem (100-)160-490(-800) $\mu \mathrm{m}$. In agara solani et sacchari, mycelia aeria bruna vel cana et sparsa vel paullo abunda. Agarum cingen coloniae flavum vel paullo brunum. Conidia eseptata, (5.0-)6.2-8.5(-8.9) × (2.3)2.6$3.7(-4.2) \mu \mathrm{m}$. Colla pycnidii vel una vel numerosa, in longitudinem (130-)200-530(-750) $\mu \mathrm{m}$. Aput $18^{\circ} \mathrm{C}$, auctus medius coloniae 27 ad $28 \mathrm{~mm}$ post 24 dies. Aput $25^{\circ} \mathrm{C}$, auctus medius coloniae 4 ad $12 \mathrm{~mm}$ post 24 dies.

Differentiating characteristics. In vivo (alfalfa roots): Conidia aseptate, (3.9-)4.2-5.3(-6.2) × (1.8-)2.0-2.9(-3.6) $\mu \mathrm{m}$. Pycnidial necks semipilose to pilose, single or multiple, with lengths up to (100-) 160-490(-800) $\mu \mathrm{m}$.

In vitro (PDA): Under continuous light at $10^{\circ} \mathrm{C}$, aerial mycelium sparse to moderately abundant and tan, brown, or gray. In mature colonies, the agar surrounding the colony is pigmented tan or yellow-brown. Conidia aspetate, (5.0-)6.2-8.5(-8.9) $\times$ (2.3)2.6-3.7(-4.2) $\mu \mathrm{m}$. Pycnidial necks single or multiple and up to (130-)200-530(-750) $\mu \mathrm{m}$ long. After 24 days in complete darkness at 18 and $25^{\circ} \mathrm{C}$, average radial growth 27 to $28 \mathrm{~mm}$ and 4 to $12 \mathrm{~mm}$, respectively.

Representative cultures. NY Chz10-18r ex $M$. sativa (Leguminaceae), New York, United States; NH 4-2-1-8r ex $M$. sativa (Leguminaceae), New Hampshire, United States.

$\boldsymbol{P}$. sclerotioides var. macrospora Wunsch \& Bergstrom, var. nov. In radices $M$. sativae, conidia eseptata et uniseptata, (4.6-)5.4-6.8(-7.1) × (1.8-)2.1-2.7(-3.2) $\mu \mathrm{m}$. Colla pycnidii vel una vel numerosa, vel paullo pilosa vel pilosa; in longitudinem (120-)180-410(-480) $\mu \mathrm{m}$. In agara solani et sacchari, mycelia aeria bruna vel cana et sparsa vel paullo abunda. Agarum cingen coloniae flavum vel paullo brunum. Conidia eseptata et uniseptata, $(6.0-) 8.2-11.1(-12.4) \times(2.0-) 2.3-4.0(-4.3) \mu \mathrm{m}$. Colla pycnidii plerumque solitaria, in longitudinem (150-)220-600 $(-750) \mu \mathrm{m}$. Aput $18^{\circ} \mathrm{C}$, auctus medius coloniae 15 ad $24 \mathrm{~mm}$ post 24 dies. Aput $25^{\circ} \mathrm{C}$, auctus medius coloniae 0 ad $3 \mathrm{~mm}$ post 24 dies.

Differentiating characteristics. In vivo (alfalfa roots): Conidia aseptate and 1-septate,(4.6-)5.4-6.8(-7.1) × (1.8-)2.1-2.7(-3.2) $\mu \mathrm{m}$. Pycnidial necks semipilose to pilose, single or multiple, with lengths up to (120-)180-410(-480) $\mu \mathrm{m}$.

In vitro (PDA): Under continuous light at $10^{\circ} \mathrm{C}$, aerial mycelium sparse to moderately abundant and tan, brown, or gray. In mature colonies, the agar surrounding the colony is pigmented tan or yellow-brown. Conidia aspetate and one-septate, (6.0-)8.2$11.1(-12.4) \times(2.0-) 2.3-4.0(-4.3) \mu \mathrm{m}$. Pycnidial necks usually single and up to (150-)220-600(-750) $\mu \mathrm{m}$ long. After 24 days in complete darkness at 18 and $25^{\circ} \mathrm{C}$, average radial growth 15 to $24 \mathrm{~mm}$ and 0 to $3 \mathrm{~mm}$, respectively.

Representative culture. ME 5-2-5r ex M. sativa (Leguminaceae), Maine, United States.

P. sclerotioides var. saskatchewanii Wunsch \& Bergstrom, var. nov. In radices $M$. sativae, conidia eseptata, (4.0-)5.0-6.1 $(-7.1) \times 1.7-2.8 \mu \mathrm{m}$. Colla pycnidii vel una vel numerosa, vel paullo pilosa vel pilosa; in longitudinem (190-)260-550(-780) $\mu \mathrm{m}$. In agara solani et sacchari, mycelia aeria bruna vel cana et sparsa vel paullo abunda. Agarum cingen coloniae flavum vel paullo brunum. Conidia eseptata, (4.0-)6.0-8.6(-9.1) $\times(1.8-)$ $2.2-3.5(-4.2) \mu \mathrm{m}$. Colla pycnidii plerumque solitaria, in longi- 
tudinem (110-)200-450(-620) $\mu \mathrm{m}$. Aput $18^{\circ} \mathrm{C}$, auctus medius coloniae 18 ad $24 \mathrm{~mm}$ post 24 dies. Aput $25^{\circ} \mathrm{C}$, auctus medius coloniae 8 ad $13 \mathrm{~mm}$ post 24 dies.

Differentiating characteristics. In vivo (alfalfa roots): Conidia aseptate, (4.0-)5.0-6.1(-7.1) × 1.7-2.8 $\mu \mathrm{m}$. Pycnidial necks semipilose to pilose, single or multiple, with lengths up to (190-)260-550(-780) $\mu \mathrm{m}$.

In vitro (PDA): Under continuous light at $10^{\circ} \mathrm{C}$, aerial mycelium sparse to moderately abundant and tan, brown, or gray. In mature colonies, the agar surrounding the colony is pigmented tan or yellow-brown. Conidia aspetate, (4.0-)6.0-8.6(-9.1) $\times$ $(1.8-) 2.2-3.5(-4.2) \mu \mathrm{m}$. Pycnidial necks up to (110-)200-450 $(-620) \mu \mathrm{m}$ long and usually single. After 24 days in complete darkness at 18 and $25^{\circ} \mathrm{C}$, average radial growth 18 to $24 \mathrm{~mm}$ and 8 to $13 \mathrm{~mm}$, respectively.

Representative cultures. MT 2-1-3 ex $M$. sativa (Leguminaceae), Montana, United States; SK 7-34 ex M. sativa (Leguminaceae), Saskatchewan, Canada.

\section{ACKNOWLEDGMENTS}

This research was funded in part by Cornell University Hatch Project NYC 153433, the Northern New York Agricultural Development Program, and a Keickhefer Adirondack Fellowship to the senior author. We thank E. Burrichter for her assistance with the laboratory work; R. Korf and K. Hodge (Department of Plant Pathology and Plant-Microbe Biology, Cornell University) for their help with microscopy and pycnidial sectioning; J. Hansen (Department of Plant Breeding and Genetics, Cornell University) for providing seeds of Vernal alfalfa for pathogenicity testing; K. Bassendowski (Agriculture and Agri-Food Canada; Saskatoon, SK), H. Darby (University of Vermont Extension), M. Dillon (Colorado Agricultural Experiment Station, San Luis Valley Research Center), B. Gossen (Agriculture and Agri-Food Canada; Saskatoon, SK), C. Grau (University of Wisconsin-Madison), M. Hall (The Pennsylvania State University), R. Kersbergen (University of Maine), D. Samac (United States Department of Agriculture-Agricultural Research Service, St. Paul, MN), H. Schwartz (Colorado State University), A. Tenuta (Ontario Ministry of Agriculture, Food, and Rural Affairs), R. Torres (New Mexico State University Extension, Taos) for their assistance in survey efforts; extension educators from Cornell Cooperative Extension, Colorado State University Extension, Montana State University Extension, University of New Hampshire Extension, New Mexico State University Extension, The Pennsylvania State University Extension, and University of Wisconsin Extension for their assistance in survey efforts; and the late F. Gray (University of Wyoming) for donating the P. sclerotioides Berg isolate.

\section{LITERATURE CITED}

1. Abeln, E. C. A., Stax, A. M., de Gruyter, J., and van der Aa, H. A. 2002. Genetic differentiation of Phoma exigua varieties by means of AFLP fingerprints. Mycol. Res. 106:419-427.

2. Aveskamp, M. M., de Gruyter, J., Woudenberg, J. H. C., Verkley, G. J. M, and Crous, P. W. 2010. Highlights of the Didymellaceae: A polyphasic approach to characterize Phoma and related pleosporalean genera. Stud. Mycol. 65:1-60.

3. Aveskamp, M. M., Verkley, G. J. M., de Gruyter, J., Murace, M. A., Perelló, A., Woudenberg, J. H. C., Groenewald, J. Z., and Crous, P. W. 2009. DNA phylogeny reveals polyphyly of Phoma section Peyronellaea and multiple taxonomic novelties. Mycologia 101:363-382.

4. Balmas, V., Scherm, B., Ghignone, S., Salem, A. O. M., Cacciola, S. O., and Migheli, Q. 2005. Characterization of Phoma tracheiphila by RAPDPCR, microsatellite-primed PCR and ITS rDNA sequencing and development of specific primers for in planta PCR detection. Eur. J. Plant Pathol. 111:235-247.

5. Berbee, M. L., Pirseyedi, M., and Hubbard, S. 1999. Cochliobolus phylogenetics and the origin of known, highly virulent pathogens, inferred from ITS and glyceraldehydes 3-phosphate dehydrogenase gene sequences. Mycologia 91:964-977.

6. Berkenkamp, B., Bittman, S., and McCartney, D. 1991. Resistance of alfalfa cultivars to brown root rot. Can. J. Plant Sci. 71:211-213.

7. Boerema, G. H., and Höweler, L. H. 1967. Phoma exigua Desm. and its varieties. Persoonia 5:15-28.

8. Boerema, G. H., de Gruyter, J., Noordeloos, M. E., and Hamers, M. E. C. 2004. Phoma Identification Manual: Differentiation of Specific and Intra-
Specific Taxa in Culture. CABI Publishing, CAB International, Oxfordshire, UK.

9. Boerema, G. H., Pieters, R., and Hamers, M. E. C. 1993. Check-list for scientific names of common parasitic fungi. Supplement Series 2c,d (additions and corrections): Fungi on field crops: Pulse (legumes), forage crops (herbage legumes), vegetables and cruciferous crops. Neth. J. Plant Pathol. 99 (Suppl. 1).

10. Camara, M. P. S., Palm, M. E., Berkum, van P., and O’Neill, N. R. 2002. Molecular phylogeny of Leptosphaeria and Phaeosphaeria. Mycologia 94:630-640.

11. Davidson, J. G. N. 1990. Brown root rot. Pages 29-31 in: Compendium of Alfalfa Diseases. D. L. Stuteville and D. C. Erwin, eds. American Phytopathological Society, St. Paul, MN.

12. Gray, F. A., Hollingsworth, C. R., Reedy, C. J., Legg, D. E., Larsen, R. C., Groose, R. W., and Koch, D. W. 2008. Pathogenicity of 14 isolates of Phoma sclerotioides, causing brown root rot of alfalfa. Can. J. Plant Pathol. 30:285-293.

13. de Gruyter, J., Boerema, G. H., and van der Aa, H. A.. 2002. Contributions towards a monograph of Phoma (Coelomycetes)-VI-2. Section Phyllostictoides: Outline of its taxa. Persoonia 18:1-53.

14. Hackett, S. J., Kimball, R. T., Reddy, S., Bowie, R. C. K., Braun, E. L., Braun, M. J., Chojnowski, J. L., Cox, W. A., Han, K. L., Harshman, J., Huddleston, C. J., Marks, B. D., Miglia, K. J., Moore, W. S., Sheldon, F. H., Steadman, D. W., Witt, C. C., and Yuri, T. 2008. A phylogenomic study of birds reveals their evolutionary history. Science 320:1763-1768.

15. Hollingsworth, C.R., Gray, F. A., and Groose, R. W. 2005. Evidence for the heritability of resistance to brown root rot of alfalfa, caused by Phoma sclerotioides. Can. J. Plant Pathol. 27:64-70.

16. Hollingsworth, C.R., Gray, F. A., Groose, R. W., and Mims, C. W. 2002. Morphological responses of Canadian and U.S.A. isolates of Phoma sclerotioides to different growth media, temperatures and light. Mycotaxon 81:331-339.

17. Hollingsworth, C. R., Gray, F. A., Koch, D. W., Groose, R. W., and Heald, T. E. 2003. Distribution of Phoma sclerotioides and incidence of brown root rot of alfalfa in Wyoming, U.S.A. Can. J. Plant Pathol. 25:215-217.

18. Hosmer, D. W., and Lemeshow, S. 2000. Applied Logistic Regression. John Wiley \& Sons, New York.

19. Irinyi, L., Kövics, G. J., and Sándor, E. 2009. Taxonomical re-evaluation of Phoma-like soybean pathogenic fungi. Mycol. Res. 113:249-260.

20. Johnson, R. D., and Lewis, B. G. 1994. Variation in host range, systemic infection and epidemiology of Leptosphaeria maculans. Plant Pathol. 43:267-277.

21. Larsen, J. E., Hollingsworth, C. R., Flor, J., Dornbusch, M. R., Simpson, N. L., and Samac, D. A. 2007. Distribution of Phoma sclerotioides on alfalfa and winter wheat crops in the North Central United States. Plant Dis. 91:551-558.

22. Larsen, R. C., Grau, C. R., Vandemark, G. J., and Hughes, T. J. 2004. First report of brown root rot of alfalfa caused by Phoma sclerotioides in Wisconsin. Plant Dis. 88:769.

23. Larsen, R. C., Hollingsworth, C. R., Vandemark, G. J., Gritsenko, M. A., and Gray, F. A. 2002. A rapid method using PCR-based SCAR primers for detection and identification of Phoma sclerotioides: The cause of brown root rot of alfalfa. Plant Dis. 86:928-932.

24. Mendes-Pereira, E., Balesdent, M. H., Brun, H., and Rouxel, T. 2003. Molecular phylogeny of the Leptosphaeria maculans-L. biglobosa species complex. Mycol. Res. 107:1287-1304.

25. Morales, V. M., Pelcher, L. E., and Taylor, J. L. 1993. Comparison of the 5.8s rDNA and internal transcribed spacer sequences of Leptosphaeria maculans from different pathogenicity groups. Curr. Genet. 23:490-495.

26. Neter, J., Kutner, M. H., Nachtscheim, C. J., and Wasserman, W. 1996. Applied Linear Statistical Models, 3rd ed. McGraw Hill, Boston.

27. O'Donnell, K., Kistler, H. C., Cigelnik, E., and Ploetz, R. C. 1998. Multiple evolutionary origins of the fungus causing Panama disease of banana: Concordant evidence from nuclear and mitochondrial gene genealogies. Proc. Natl. Acad. Sci. USA 95:2044-2049.

28. Posada, D., and Crandall, K. A. 1998. MODELTEST: Testing the model of DNA substitution. Bioinformatics 14:817-818.

29. Sanford, G. B. 1933. A root rot of sweet clover and related crops caused by Plenodomus meliloti Dearness and Sanford. Can. J. Res. Sect. C 8:337-347.

30. Somai, B. M., Dean, R. A., Farnham, M. W., Zitter, T. A., and Keinath, A. P. 2002. Internal transcribed spacer regions 1 and 2 and random amplified polymorphic DNA analysis of Didymella bryoniae and related Phoma species isolated from cucurbits. Phytopathology 92:997-1004.

31. Sugita, T., Nishikawa, A., Ikeda, R., and Shinoda, T. 1999. Identification of medically relevant Trichosporon species based on sequences of internal transcribed spacer regions and construction of a database for Trichosporon identification. J. Clin. Microbiol. 37:1985-1993.

32. Swofford, D. L. 2002. PAUP*. Phylogenetic Analysis Using Parsimony (* and Other Methods), version 4. Sinauer Associates, Sunderland, MA. 
33. van der Aa, H. A., Boerema, G. H., and de Gruyter, J. 2000. Contributions towards a monograph of Phoma (Coelomycetes) VI-1. Section Phyllostictoides: Characteristics and nomenclature of its type species Phoma exigua. Persoonia 17:435-456.

34. van der Aa, H. A., Noordeloos, M. E., and de Gruyter, J. 1990. Species concepts in some larger genera of the Coelomycetes. Stud. Mycol. 32:3-19.

35. Vincenot, L., Balesdent, M. H., Barbetti, M. J., Sivasithamparam, K., Gout, L., and Rouxel, T. 2007. Occurrence of a new subclade of Leptosphaeria biglobosa in Western Australia. Phytopathology 98:321-329.

36. Wang, H., Hwang, S. F., Chang, K. F., Gossen, B. D., Turnbull, G. D., and Howard, R. J. 2004. Assessing resistance to spring black stem and leaf spot of alfalfa caused by Phoma spp. Can. J. Plant Sci. 84:311-317.

37. White, T. J., Bruns, T., Lee, S., and Taylor, J. 1990. Amplification and direct sequencing of fungal ribosomal RNA genes for phylogenetics. Pages 315-322 in: PCR Protocols: A Guide to Methods and Applications. M. A. Innis, D. H. Gelfand, J. J. Sninsky, and J. W. White, eds. Academic
Press, New York.

38. Wunsch, M. J., Dillon, M. A., Torres, R., Schwartz, H. F., and Bergstrom, G. C. 2008. First report of brown root rot of alfalfa caused by Phoma sclerotioides in Colorado and New Mexico. Plant Dis. 92:653.

39. Wunsch, M. J., Kersbergen, R., Tenuta, A. U., Hall, M. H., and Bergstrom, G. C. 2009. First report of brown root rot of alfalfa caused by Phoma sclerotioides in Maine, Ontario, and Pennsylvania. Plant Dis. 93:317.

40. Wunsch, M. J., Schindelbeck, R. R., van Es, H. M., and Bergstrom, G. C. 2007. Distribution, impact, and soil environment of Phoma sclerotioides in northeastern U.S. alfalfa fields. Plant Dis. 91:1293-1304.

41. Zar, J. H. 1999. Biostatistical Analysis, 4th ed. Prentice Hall, Upper Saddle River, NJ.

42. Zwickl, D. J. 2006. Genetic algorithm approaches for the phylogenetic analysis of large biological sequence datasets under the maximum likelihood criterion. Ph.D. dissert., The University of Texas, Austin. 